\title{
The distribution of top incomes in former British West Africa ${ }^{1}$
}

\author{
A B Atkinson, Nuffield College, Oxford and INET Oxford
}

1. Introduction

2. Using income tax data

3. Putting the data in context: total population

4. The income taxpayers

5. The upper tail of the income distribution

6. Putting the data in context: control totals for income

7. Top income percentiles and shares

8. Conclusions

\section{Introduction}

This paper explores what can be learned about the upper tail of the income distribution in the British West African colonial territories, exploiting the administrative statistics on the operation of the colonial personal income tax. These statistics covering the middle of the twentieth century have definite limitations, but then little is known about the distribution of income in the colonies at that time. In historical studies of the development of the economy of Ghana (previously the Gold Coast), for example, the absence of adequate data is a constant theme: "poor statistics conspire to prevent even the roughest estimates of the overall distribution of the national income" (Killick, 1978, page 80) or "data on income distribution in Ghana are not readily available" (Huq, 1989, page 56). Writing about four countries, including Ghana and Nigeria, Phillips (later Commissioner of the Ministry of Finance in Ogun State in Nigeria), concluded that "studies of income distribution in these countries have been thin on the ground; in the few analyses that exist, size distribution has received very scant attention ... in most respects, long timeseries data are hard to come by" (1975, page 1$)$.

There are many questions that can be addressed. What was the position of colonial elites during the period of British rule and how far did they appropriate resources. What was the distribution among the rich and how did their position compare with that of the rich in the United Kingdom? Did the distribution follow the Pareto law? How did income concentration evolve in the colonial period? Did inequality fall in the latter years of colonial rule, as the British government became more concerned with economic and social development? Evidence about the distribution is needed if we are to evaluate,

\footnotetext{
${ }^{1}$ The research for this paper has been supported by INET at the Oxford Martin School, where it forms part of the Programme for Economic Modelling (EMOD), and by the ESRC grant RES-16725-0640. I am most grateful to Facundo Alvaredo, Friedrich Geiecke and Salvatore Morelli for their comments and assistance.
} 
for example, the claim that Ghana began from a position of relatively low inequality. Killick (1978) opens his discussion of income distribution in Ghana by saying that "traditional African society is often thought of as naturally egalitarian", citing both Nkrumah's description of the "socialist egalitarianism of the traditional African society" (1964, page 78) and the assertion by Myrdal (1956, page 399) that in the Gold Coast income was less unequally distributed than in the United States. Killick goes on to say that

"there are plausible a priori reasons for expecting incomes in Ghana to have relatively low inequality. There are no large land-owners who could be compared with those of the Indian sub-continent, the latifundia of Latin America, or the former white settlers of East Africa. Also lacking is an entrepreneurial elite with command over accumulations of wealth and income comparable, let us say, to the small number of families who have controlled so much of Pakistan's industry. There is no powerful aristocracy, as in Ethiopia, nor has exploitation of the peoples of the hinterland by a coastal elite been characteristic of Ghana, as it has been of Liberia" (1978, page 80).

It is therefore of considerable interest to ask whether there is statistical evidence to support the view that colonial Ghana was less unequal than other former British colonies and protectorates.

Answers are of interest in their own right, but also because they cast light on the colonial heritage. In West Africa, Sierra Leone has been taken as a leading example of a country characterised by "extractive institutions". According to Acemoglu and Robinson, there were "historical and institutional factors stacking the cards against the development of the type of inclusive economic and political institutions and policies that would have stimulated economic growth in Sierra Leone” (2013, page 181). The income tax returns only tell part of the story - certainly missing illegal activity - but they provide one insight into the extent of inequality.

The paper provides evidence about top incomes in the Gambia from 1944 to 1974, Ghana from 1943 to 1959, federal Nigeria from 1952 to 1959 and Sierra Leone from 1945 to 1960. The underlying income tax data are described in section 2. There are several difficulties in using these data, notably those of setting the figures in overall context. Little is known about the aggregates of population and national income. "Population censuses proper began to be taken in many African territories only after 1945. While some of the British West African territories had attempted complete enumeration in 1931, others began censuses proper only recently" (Ady, 1963, page 54). The problems of establishing the control totals for population are described in Section 3. The numbers and characteristics of those paying income tax are described in section 4 . The results regarding the shape of the upper tail are presented for all four countries in section 5 . 
Arriving at a control total for income poses even more of a challenge. As was explained by D T Jack, in his survey of Sierra Leone in 1958, "there has been no official attempt yet to estimate the magnitude of national income (1958, page 1). As is discussed in Section 6, this limits what can be said about income shares and income levels. In fact, the limited national accounts information for the years in question means that there are income control totals for only two of the four countries: Ghana and Nigeria. Section 7 describes the top income shares in these two countries. The main findings of the paper as a whole are summarised in section 8.

\section{Using income tax data}

The income taxes in the different countries had similar forms, being in general based on the Colonial Model Tax Ordinance. The tax was assessed in year $(t+1)$ on the total income accruing in year $t$. The latter is referred to here as Income Year $\mathrm{t}(\mathrm{IYt})$. The introduction of the tax in each of the countries is described in each case below, together with a summary of the published statistical information. The key data are the tabulations of taxpayers by ranges of income, showing the total numbers in each range and their total income.

\section{Ghana (Gold Coast)}

"Income tax administration in Ghana started in September 1943 with the passing into law of the Income Tax Bill on 22 September 1943" (website of the Internal Revenue Service of Ghana). The income tax year ran from April to March, and the tax took effect from 1 April 1944. The tax was levied on all income arising during the year ending 31 March preceding the year of assessment, so that the first year covered ("income year") is for that starting on 1 April 1943, referred to below as 1943. The tax was levied on individuals or married couples (referred to as the "tax unit"): "a husband is responsible for the tax on his wife's income provided that she is living with him. Both incomes are added together for the purpose of deducting personal allowances and assessing the balance on the graduated scale for the purpose of ascertaining the total tax payable" (Brewster, 1954, page 51).

Tax was levied on "chargeable income", defined as gross income minus deductions and allowances. In 1947, the deductions included £150 per single taxpayer (£200 for unmarried women) and an additional £200 for a married man (source: Colonial Annual Report, Gold Coast 1947). The rates of tax varied from $3 \mathrm{~d}$ in the $€\left(1 / 80^{\text {th }}\right)$ to 50 per cent on chargeable income in excess of $£ 10,000$. The deduction was later increased to $£ 200 \mathrm{for}$ all, and the rates increased to run from $6 \mathrm{~d}$ in the $\mathrm{f}\left(1 / 40^{\text {th }}\right)$ to 57.5 per cent above $\mathrm{f} 10,000$. To 
put these amounts in perspective, in $1951, £ 10,000$ was some 90 times the estimated average income.

In the Report on the Income Tax Department for the first two years of operation (1944-45 and 1945-46, the tax authorities published the distribution of assessed incomes for income year (IY) 1943, giving the number of people and total incomes by ranges. Later reports contained data for 1951 to 1957, and data for 1958 and 1959 were published in the Statistical Yearbooks for 1962 and 1963. At this point, the introduction of Pay As You Earn (PAYE) with effect from 1 July 1961 meant that data ceased to cover the whole population (the published information only applied to the self-employed). The data studied here cover therefore the period from IY1943 to IY1959 - see Table A1.

\section{Nigeria}

Nigeria is a federal state and responsibility for the operation of the personal income tax was initially shared between the federal and regional governments. At the outset, the federal Inland Revenue Department was responsible for the income tax levied on non-Africans throughout Nigeria and on Africans receiving incomes within the Municipal Area of Lagos. The Lagos Tax Office came into being on 1 April 1937, administering the Colony Taxation Ordinance, 1937, (Annual Report of the Inland Revenue Department (Lagos Tax Office) for the year ending $31^{\text {st }}$ March, 1938, Sessional Paper No 20 of 1938). The subsequent Income Tax Ordinance, 1943, "laid down complex definitions of income, allowable deductions, personal reliefs and exemptions together with procedures for individual assessment and collection. The administration was in the hands of the Federal tax authority" (Report of the Commissioner of Revenue for Northern Nigeria 1965, pages 1 and 2). The taxation of Africans outside Lagos was the responsibility of the regions (Eastern, Northern and Western Nigeria), which accounted for almost all of the population. ${ }^{2}$ Under the Direct Taxation Ordinance, 1940, "a general tax was levied on the annual incomes of indigenous communities and individuals and provision was made for a cattle tax. A capitation rate ... was fixed by the Regional Government and each Native Authority was then responsible for ascertaining its own required revenue. The total tax to be levied was apportioned within each community by reference to the wealth of its members. A basic rate of general tax was common but where individual incomes could be computed they were assessed by local committees and subjected, without relief for personal or social responsibilities, to graduated rates of tax" (same source). In the course of the 1950 s, the individual regions began to introduce a personal income tax for Africans. In 1956, the Eastern Region enacted an income tax law covering

\footnotetext{
${ }^{2}$ The 1952-3 census (Federation of Nigeria, Annual Abstract of Statistics, 1961, Table 10) shows 54.0 per cent living in the Northern Region, 23.2 per cent in the Eastern Region, 19.5 per cent in the Western Region, and 0.9 per cent in Lagos Township (and 2.4 per cent in Southern Cameroons).
} 
Africans, described by the Finance Minister as "of an entirely revolutionary nature in Nigeria" (Foreword to the Annual Report of Internal Revenue Division, 1956-57).

Federal-wide negotiations in 1959 and 1960 led to agreement that, while the federal government would remain responsible for taxes on the profits of companies, the regions should have basic jurisdiction over the taxation of the incomes of persons and that this should be extended to non-Africans. Regions enacted personal tax laws, such as the Northern Nigeria Personal Tax Law that came into effect on 1 April 1962. As a result, the statistics began to be published on a regional basis, initially for three regions (Eastern, Northern and Western), but in 1963, two provinces were detached from the Western Region to form the new Mid-Western Region. In 1967, the regions were replaced by 12 states. In 1976 the number of states increased to 19, including the Federal Capital Territory (Abuja). The number of states increased further to 21 in 1987, 30 in 1991, and 36 in 1996. The distributional information became therefore dispersed. According to Phillips (1975, page 30), "most of the States publish no income tax statistics save those which appear in the budget estimates ... the only exceptions are Western and Eastern Nigeria which have published data on the distribution of income taxpayers by assessable income for 1962/ 63 to $1967 / 68$ ". He goes on to say that the two States "are by no means representative".

In this paper, use is only made of the federal tax statistics. This limits the time period covered and means that the statistics do not cover African taxpayers outside Lagos. While statistics have been published by the individual regions, the use of these data is complicated by the difficulties in securing control totals and by the later proliferation of regions. For Federal Nigeria as a whole, we have data starting in 1952: "the year 1952-53 is the first year in respect of which a statistical report ... was prepared by the Government Statistician" (Report on the Inland Revenue Department for the three years ended $31^{\text {st }}$ March, 1953, 1954 and 1955, page 6). The data on the distribution of taxpayers by ranges of gross income published in the Digest of Statistics (subsequently Annual Abstract of Statistics) and in annual reports of the Federal Inland Revenue Department cover the period 1952-1959 - see Table A2 - up to the transfer of responsibility to the regions.

\section{Sierra Leone}

The income tax was introduced under the Income Tax Ordinance No 1 of 1943, passed on $31^{\text {st }}$ May, 1943 and came into force on $1^{\text {st }}$ April 1944. This information comes from the Report of the Income Tax Department Sierra Leone 1946-1947, para 2. This series of reports, later the Annual Report of the Income Tax Department, is referred to in what follows as simply the "Annual Report" (abbreviated to AR). When the income tax was being introduced in 
Sierra Leone, questions were asked in the British House of Commons about the incidence of the tax on the African population. In replying, Colonel Stanley, then Secretary of State for the Colonies, made clear that Africans were liable for taxation, but that since "liability arises only on incomes above £150 in the case of single men without dependants and above $\mathrm{E350}$ in the case of married men without children ... the great bulk of the African population is therefore exempt" (Hansard, 14 July 1943). The sources of the income tax tabulations are given in Appendix Table A3. For the years 1946 and 1947 only amounts were published by ranges; the numbers have been imputed applying the cell means in IY1945.

\section{The Gambia}

The income tax was introduced in the Gambia in 1940. Information on the distribution of taxpayers by ranges of assessable income was published in the Appendices to the Financial Report. The data were published on a regular basis covering the income years 1944 to 1959 . There was then a hiatus, with no statistics being published for the years 1960 to 1962. A further complication is that, with effect from 1962, "a new low-scale tax was introduced, payable by those persons earning gross income of not less than $£ 150$ who are not assessable under the main scale" (Colonial Office, Gambia 1962 and 1963, page 31). This latter provision was referred to as the "fourth schedule" (initially, the fifth schedule), in contrast to the original "first" schedule. This meant that, when publication was resumed, the data related to two different schedules of taxpayers. Not only do the ranges not co-incide but the first schedule tabulations were now presented in terms of chargeable income, after the deduction of personal allowances. In combining these two tables, the assumption has been made that assessable income is equal to chargeable income plus the single person's allowance (at that time £200). To the extent that over a half of those taxed under the first schedule claimed a married allowance (£350) and that there were other allowances, such as those for children, this causes the upper incomes to be under-stated. The sources of the income tax tabulations are given in Appendix Table A4.

\section{Conclusion}

In using income tax data, the research reported here is following a long line of enquiries, including the original Pareto curves. The strengths and weaknesses of the source have been extensively discussed in the recent literature on top incomes initiated by Piketty (2001). The data are drawn from an administrative process and reflect in their definitions of income and the tax unit the underlying legislation rather than any concept of equity. The 
administrative process doubtless had many shortcomings, and tax data are affected by avoidance and evasion.

Incomplete coverage of both taxpayers and income is likely to be important in the countries studied here. As was noted by Orewa, "tax evasion and avoidance are among the most serious tax problems facing the whole of Nigeria" (1962, page 16). He quotes a figure for the Western Region in 1957 of evasion among male taxpayers of 26 per cent (1962, page 19) and concludes that, not surprisingly, evasion is higher among the self-employed than among employees. The extent of tax compliance depends on the resources allocated, which were limited. The Income Tax department of Sierra Leone commented that "with an effective assessing staff of 6 inspectors it is physically impossible to cover a country the size of Sierra Leone and ensure that no potential tax payers are missed" (Annual Report for the year ended $31^{\text {st }}$ March 1961, para 1). It is important to remember that, in the years studied, the income tax was a recent introduction and that it would have taken time for the tax administration to develop.

The data must therefore be treated with considerable caution. At the same time, they provide an insight into the distribution of income in a period about which we have virtually no other empirical information.

\section{Control totals for population}

The people recorded in the income tax statistics have to be related to the population as a whole. The total number of tax units is estimated from total population by taking the proportion aged 15 and over (the "adult population") and subtracting the proportion who are married women. Each of these elements is discussed in turn. ${ }^{3}$ It should be noted that the definition of the income unit is that relevant to the income tax; the total of tax units bears no necessary relation to the total of households as might be defined in terms of income-sharing or joint consumption. A taxpayer may have obligations that extend beyond the narrow administrative definition; and the boundaries may be drawn in a different way. The tax unit control total should be seen simply as a scaling factor.

\section{Ghana (Gold Coast)}

The estimation of control totals for taxpayers poses serious problems in view of the limitations of the demographic data, particularly in the early part

\footnotetext{
${ }^{3}$ The population estimates here were completed before I saw the study by Frankema and Jerven (2014) on African population 1850 to 2010. They discuss the specific cases of Ghana and Nigeria, and reference is made to these below.
} 
of the period considered. The uncertainty surrounding the population numbers is well illustrated by the broad statement in the Colonial Annual Report Gold Coast 1946 that "the population is between 4 and $4 \frac{1}{2}$ millions" (1946, page 13). The total population figures used here are based on the US Census Bureau International Database (the source used by Maddison, 2003), referred to as USCB. (The link is http://www.census.gov/population/international/data/idb/informationgatewa y.php ). These figures cover the period from 1950. For the 1940s, it is necessary to link to the censuses for 1931 and 1948. Here it should be noted that there is evidence of considerable under-enumeration in the censuses. According to the 1931 Census Report (1931, page 123-4), the results were believed to be more accurate than in previous censuses, but there is reference to under-enumeration of between 2 and 10 per cent. The total population, covering the Colony, Ashanti, the Northern Territories and Togoland, was estimated at 3,163,464. Of this total, less than 0.1 per cent, 3,078, were nonAfricans. In 1948, the total population, covering the Colony, Ashanti, the Northern Territories and Togoland, was estimated at 4,118, 450, of which 6,770 were non-Africans (of whom 4,211 were British and 1,213 were Lebanese). The 1948 results were however called into question by the subsequent 1960 census, since the implied growth rate of the population (4.2 per cent per year) appeared implausible (see Birmingham, Neustadt and Omaboe, 1967, page 22). As is explained in the 1960 report, there are good reasons to believe that the findings were more reliable: it was "the first real application of modern census techniques" (1960 Population Census of Ghana, volume I, page v). It noted that "previous censuses suffered partly from lack of support from the public and this resulted in considerable under-enumeration in certain areas of the country" (page v). ${ }^{4}$ If the 1948 figure is disregarded, the growth rate of population between 1931 and 1960 is 2.635 per cent per year, ${ }^{5}$ which would have implied a figure in 1948 of 4.9 million (instead of 4.1 million). ${ }^{6}$ This is closer to the 5.3 million in 1950 in the USCB series used here. This suggests substantial under-enumeration in the 1948 census. $^{7}$ In view of this, I work back from the USCB estimate for 1950 and for 1943-1949 take the figures implied by a growth rate of 2.6 per cent per year, resulting in a figure of 4.4 million in 1943.

According to the 1931 Census, "the grouping of the population by ages is difficult since the estimates of Age are almost impossible to ascertain with any degree of accuracy" (1931, volume 1, page 166). Moreover, the distinction

\footnotetext{
${ }^{4}$ The former head of geography at Adisadel College, Cape Coast, from 1954 to 1959 reported that "the general opinion of those with any interest was that [the 1948 census] badly undercounted the population" (letter from Bert Perry to LSE Magazine, Winter 2007, page 27).

${ }^{5}$ The figure given in Birmingham, Neustadt and Omaboe (1966, page 22) is 2.7 per cent.

${ }^{6}$ Frankema and Jerven (2014, Table 8) similarly suggest that the 1948 figure is too low; their revised estimate is 4.6 million.

${ }^{7}$ The same issue arose with respect to the 1970 census. The total population recorded in 1970 was $8,559,000$ but, according to Killick (1978, page 91), this was known to be underenumerated and he reports an estimate of 8,695,000.
} 
between children (under 15) and adults in this and other earlier censuses "was not carried through in the same manner for both sexes since, as in many other African countries, females who should have been counted as children were considered to be adults" (Kuczynski, 1948, page 435). Here I have worked with the estimates of population aged 15 and over given by the United Nations (UN) in The Size and Age Distribution of the World Populations 1994, page 386. The UN adult proportion for 1960 is almost the same as that from the 1960 census, but the 1950 figure is lower than that shown by the 1948 census ( 54.9 compared with 60.7 in 1948). (The census figures are from Kay, 1972, page 311.) The UN proportions are given at 5 year intervals, and have been interpolated linearly; the 1950 figure was extrapolated back to 1943 linearly on the basis of the change between 1950 and 1955.

If information on age was difficult to obtain in earlier censuses, that on marital status was non-existent. According to the 1931 Census, "statistics concerning the marital condition of the inhabitants of the Gold Coast are not obtainable" (Cardinall, 1932, volume 1, page 168). The same report went on to say

"The Gold Coast ... does not regard the bachelor or the spinster with favour; and the religion of animism which is so involved with ancestorworship practically enforces [marriage]. It can therefore be safely stated that almost the total adult population of the country is married, in the case of males over the age of 25 , and in the case of females about the age of 16 or 17 . No figures are possible to prove this statement, however; it can only be deduced from reasoning and observation" (1931, volume 1 , page 169).

If it is assumed that all women aged 15 and over are married, then this would have given a figure of 29.5 per cent of the total population. However, Kuczynski (1948, page 438) casts considerable doubt on this reasoning, and cites evidence that "numerous adult females" are not married.

The collection of data on marital status was taken up in the Post Enumeration Survey carried out following the 1960 Population Census. Marriage is, according to the report, a "very complex" factor in African society, governed by tribal rules and local customs. It warns that "one cannot pretend that a statistically adequate picture of marriage and cohabitation has been given by the material presented", but goes on to say that "it may nevertheless be considered as a major statistical contribution, rarely encountered in censustype enquiries" (1960 Population Census of Ghana, volume VI, page xiv). The results (Tables $\mathrm{C} 1$ and $\mathrm{A} 3$ ) show that in 1960 there were 1,374,180 married women out of a total population (men and women) of $6,632,990$, or a ratio of 20.7 per cent. This may be compared with the ratio of all women aged 15 and over to the total population, which in 1960 was 27.6 per cent. From limited evidence of this kind, it appears that an allowance of 20 per cent would not be unreasonable, and this has been applied for the whole period 1943 to 1960. 
The resulting estimates of total tax units are shown in Table A.2. For the non-African population, the 1931 Census shows that, of the total of 3,078, 138 were aged under 15 and 425 were married women, so that the total of nonAfrican tax units was 2,515. They accounted for 0.2 per cent of the total tax units. The 1948 Census showed that there were 6,770 non-Africans, of whom 665 were aged under 15 and 1,105 were married women, so that the total of non-African tax units was 5,000. They accounted for 0.28 per cent of total tax units. (The under-enumeration in the 1948 Census discussed above is unlikely to have affected the non-African population.)

\section{Nigeria}

Population statistics for Nigeria have been the subject of much discussion. Here I have, as for the other countries, relied for national estimates on those in the US Census Bureau International Database, USCB (downloaded from the website of Angus Maddison, as the USCB figures were currently unavailable). According to Lury, the Nigerian Census results have been discredited" (1963, page 412). For example, the figure given for the Nigerian 1963 census was 55.7 million, which was much higher than that of Maddison (website), which is 45.3 million, or some fifth lower. The United Nations 1979 Demographic Yearbook (page 182) noted that the Nigerian "data have been adjusted for estimated over-enumeration [in the 1963 census]". ${ }^{8}$

The proportion of the population aged 15 and over is taken from the United Nations The Size and Age Distribution of the World Populations 1994, page 614, linearly interpolated. The Nigerian population censuses of 1952-3 for the three regions did not contain any information on marital status. According to information given by Kuczyinski (1948, page 611), for selected areas of the Northern Region, in 1931 the ratio of married women to the total population was 25.8 per cent. Given this limited, and dated, information, I have taken a percentage of 20 per cent in line with the other West African countries.

\section{Sierra Leone}

The population figures used here are based on the US Census Bureau International Database, USCB, covering the period from 1950. Figures for earlier years are obtained using the 1947-48 enumeration of the Colony and Protectorate, extrapolated backwards linearly on the basis of the increase since the census of 1931. The figure for 1949 is interpolated between 1947-8

\footnotetext{
${ }^{8}$ Frankema and Jerven (2014, Table 7) in their new estimates revise the 1963 census figure downwards, but rather less to 48.2 million, which leads to their 1953 figure being revised upwards by rather more, to 39 million, compared with the 33.8 million used here (in place of the census total of 30.4 million). It is possible therefore that the number of tax units is understated by the figures employed here.
} 
and the $31^{\text {st }}$ December 1950 figure given in the Colonial Office Report on Sierra Leone for the year 1951, page 9. From the population totals, the control total for total income units is obtained by subtracting the proportion aged 15 and under, and the proportion who are assumed to be married women. The proportion of the population aged 15 and over is obtained from the UN The Size and Age Distribution of the World Populations 1994, page 702), which gives figures from 1950 at 5 yearly intervals, which have here been interpolated linearly. The 1950 proportion is assumed to apply to 1945 to 1949 . There is no information for this period on the proportion married, but, on the basis of evidence from Ghana, it has been assumed that the ratio of married women to the total population was 20 per cent. In 1947-8 enumeration of population, Europeans and Americans accounted for 964 out of $1,858,275$ people recorded as living in Sierra Leone ( 0.05 per cent); there were a further 2,074 Asians (0.11 per cent) (source: Colonial Office Report on Sierra Leone for the year 1949, page 11).

\section{The Gambia}

The total population figures used here from 1950 are based on the USCB database. (the source used by Maddison, 2003), referred to as USCB. For earlier years, the Digest of Colonial Statistics, March-April 1952, Table A, contains a figure for the population in 1931, which implies an annual growth rate of the population of 1.58 per cent between 1931 and 1950. The 1950 USCB figure has been extrapolated back to 1944 on this basis. The proportion of the population aged 15 and over is taken from the United Nations (UN), The Size and Age Distribution of the World Populations 1994, page 374. The UN proportions are given at 5 year intervals, and have been interpolated linearly; the 1950 figure was extrapolated back to 1944 linearly on the basis of the change between 1950 and 1955. It has been assumed, on the basis of the evidence from Ghana, that married women accounted for 20 per cent of the population.

\section{Conclusion}

The control totals for tax units given in Table $\mathrm{A} 2$ are at best approximate, and should be interpreted with care. But it should be remembered that they are only being used here for a limited object. They are designed to provide a sense of scale, and for this purpose they seem adequate. 


\section{The income taxpayers}

The evidence presented here is limited to the very top of the distribution, since the income tax was only paid by a small minority. In Ghana, the tax authorities note that "initially, the Department collected tax from only a few limited liability companies and a very small number of individuals" (website of the Internal Revenue Service of Ghana). The statistics on taxpayers as a percentage of total tax units shown in Figure 1 bear out this statement: only a small minority of the population of colonial Ghana paid income tax. At the outset, taxpayers numbered some 0.2 per cent of the total, although they rose to reach more than 0.5 per cent.

The income tax was of growing importance in Ghana at this time. According to Cox-George, the institution of the income tax "gave an immense accession of strength to the revenues of the territory" (1973, page 25). The expansion in the proportion of taxpayers in part reflects the fact that the income tax threshold did not rise fully in line with money wages. Between 1943 and 1951, the index of money wages rose by 78 per cent (Ewusi, 1971, Table 9), but the single person's allowance rose only from £150 to £200. There was however a further increase in the allowance to $\mathrm{E350}$ from IY1954 (Supplement No 1 to Brewster, 1954), which restored the relation with the money wage index (and it may be noted that the proportion of taxpayers fell in that year). It is probable therefore that much of the expansion reflected the real growth of the economy and the increased effectiveness of the income tax administration. In the latter context, early official reports clearly recognised that there remained considerable scope for improvement. The Report on the Income Tax Department for the year 1953-4 commented that there had been "an increase in the number of self-employed persons brought into charge, but the field for expansion remains very large. The limiting factor continued to be the shortage of staff capable of dealing with accounts cases" (page 2).

What about the other West African countries? In the Gambia, the proportions were similar to those in Ghana in the 1950s and rose to be nearly 3 per cent by 1974. The jump in 1965 shown in Figure 1 was the result of the recasting of the tax schedule. The 1965 Annual Report of the Inland Revenue Division (para 4) notes the threefold increase in the number of assessments. In Sierra Leone, the proportions were similar in the 1940s and rose at the end of the 1950s. The proportion in Nigeria was around 1 per cent and appeared stable, reflecting the longer period of operation.

Who were these taxpayers? In Ghana, according to Gocking, "the tax fell almost entirely on non-African sources of income" (2005, page 78). Numerically, this could be correct, given the earlier estimate of the percentage of non-African tax units as 5,000 in 1948, whereas the total number of taxpayers was 5,693. At the same time, there was some "headroom" for African taxpayers, and some non-Africans were not paid enough to be subject 
to income tax. ${ }^{9}$ Certainly the income tax was not just paid by expatriates, as is clear from the analysis of personal taxpayers by nationality in IY1951 contained in the Report on the Income Tax Department for the year 1953-4 (Table XV):

$\begin{array}{lrr}\text { Nationality: } & \text { Number (per cent) } & \text { Income } \text { E000 (per cent } \\ & & \\ \text { Gold Coast } & 1,073(16.2) & 1,180(14.9) \\ \text { Other African territories } & 148(2.2) & 206(2.6) \\ \text { India } & 138(2.1) & 154(2.3) \\ \text { UK and Commonwealth } & 3,969(59.8) & 4,273(54.1) \\ \text { Other European and American } & 699(10.5) & 920(11.7) \\ \text { Middle East } & 613(9.2) & 1,163(14.7)\end{array}$

Over time, the number of taxpayers who were nationals increased and by IY1957 nationals of Ghana accounted for 42 per cent of taxpayers (1961 Statistical Yearbook, Table 149).

The annual report of the Nigerian Federal Inland Revenue Department for the year 1957/58 showed the distribution of taxpayers with incomes of $£ 500$ and over by nationality in IY1956:

$\begin{array}{lrr}\text { African } & 1,890 & (14.5 \%) \\ \text { European } & 10,284 & (78.9 \%) \\ \text { Levantine and Asiatic } & 863 & (6.6 \%)\end{array}$

It should be noted that the figures for Africans refer only to those receiving income from the Lagos Township. There is also a breakdown by employment. Of the total, 42.6 per cent were government officials, of whom 839 out of 5,553 were Africans. Of the remainder, 11.4 per cent were self-employed, nearly half of whom were African.

For Sierra Leone, there are figures on the composition of taxpayers for IY1948, which show that Africans accounted for 480 out of 2,093 individual taxpayers (Colonial Office, 1952, volume III, page 88). There is also information on the sources of income. In IY1950, for example, 513 government employees were assessed and 356 non-government employees, but there were 651 assessments on trades and professions (non-company) and 23 pensioners (Annual Report of the Income Tax Department for the year ended $31^{\text {st }}$ March 1952, page 11). Trades and professions accounted for 48 per cent of the total assessable income (excluding companies).

\footnotetext{
${ }^{9}$ The 1931 Census, for example, showed that there were 167 missionaries (Cardinall, 1932, page 258).
} 


\section{Conclusion}

The income tax was paid by a very small minority, but taxpayers were not only expatriates nor only government officials.

\section{Upper tail of the distribution}

As we have seen, income taxpayers were a small minority. We begin by examining how incomes were distributed among this small group. If the top 0.1 per cent receive $\mathrm{x}$ per cent of total income, can we say how much of this $\mathrm{x}$ per cent goes to the top half of this group? This calculation does not make use of the income control totals. If the upper tail of the distribution has the Pareto form, then the shares-within-shares are governed by the Pareto coefficient, $a$. The formula is given by $\log \left\{S_{1} / S_{2}\right\}=(1-1 / \alpha) \log \left\{\left(1-F_{1}\right) /\left(1-F_{2}\right)\right\}$, where $S_{i}$ denotes the income share and $\mathrm{F}$ is the cumulative distribution. This is most easily interpreted in terms of the fact that, where the Pareto distribution holds, the mean income of people above $y$ is given by $\alpha /(\alpha-1)$. This expression, $B=\alpha /(\alpha-$ 1), referred to as the Beta coefficient, or as the inverted Pareto coefficient (see Atkinson, Piketty and Saez, 2011, page 13), is used in the analysis that follows. A higher value for Beta means more concentration of income at the top. $^{10}$

The Beta coefficients for the Gambia over the period from 1944 to 1974 evaluated using different proportions of the population are shown in Figure 2. From this, several conclusions may be drawn. The first is that the period up to independence in 1965 saw a reduction in the degree of concentration. From values around 2.5 in 1944, the Beta coefficients had reached 2.0 by 1951 and fell below 1.5 by the 1960s. This means that, whereas in 1944 people looking up the distribution would have seen that those above had $2 \frac{1}{2}$ times their income, by the end of the 1950 s the relative advantage was more like 50 per cent. This is a significant change. Much of the change took place in the first half of the 1950s. The second conclusion is that the Beta coefficients rose after independence. There is a striking $\mathrm{U}$-shaped pattern with the bottom of the $\mathrm{U}$ in 1965 . By the early 1970 s, the value of Beta was around 1.75. The point is underlined by the comparison with the UK, also shown in Figure 1. At the outset, the distribution was more concentrated than in the UK; by independence it was distinctly less concentrated; but by 1974 the positions were reversed.

The Beta coefficients calculated using different population proportions follow similar time paths in the Gambia. At the same time, there are

\footnotetext{
${ }^{10}$ Since the income data are grouped, and the intervals do not in general coincide with the percentage groups of the population with which we are concerned (such as the top 0.1 per cent), we have to interpolate in order to arrive at the shares of total income. In the results presented here, the interpolation is based on the mean-split histogram - see Atkinson (2005).
} 
differences in the levels. In 1964, just before independence, there is a clear ranking. Beta calculated from the share of the top 0.1 per cent in the share of the top 0.25 per cent is 1.48 ; it falls to 1.35 if we consider the share of the top 0.05 per cent within the top 0.1 per cent; to 1.28 if we consider the share of the top 0.01 per cent within the top 0.05 per cent; and reaches 1.24 if we look at the share of the top 0.005 within the top 0.01 per cent. If the upper tail were in fact Pareto in form, then Beta should be the same wherever the distribution is sliced. In the case of the Gambia, the Pareto assumption does not hold. This may be seen clearly if we consider at income level y the ratio to $y$ of the average income of all those with incomes $y$ or higher. This ratio, denoted by $M$, may be seen as a function of $(1-F)$. Figure 3 shows the $M$ curves for even- numbered years in Gambia before independence; Figure 4 covers the period from 1964 to 1974. (In each case, the curves are based on a minimum of 40 observations per year.) In both cases, there is a strong downward slope. The $M$ curve in 1974 is more or less parallel to that in 1964. Concentration has increased but the distribution continues to depart from the Pareto in the same way.

The Beta coefficients for Ghana over the period from 1943 to 1959 evaluated using different population proportions are shown in Figure 5. One has to be cautious in comparing 1943 with 1951, since 1943 was the first year of operation and it undoubtedly took time for the administration to be established. If the extension of the reach of the tax authorities brought into the tax net people who were liable but in the lower ranges, then this would have the effect of lowering the Beta coefficient. But over the first part of the 1950 s there was a fall in the Beta coefficients. By independence, the value was around 1.7, which placed Ghana on much the same level as the UK, and as more concentrated than the Gambia. There are not sufficient years to assess the impact of independence, but there are no signs for the years 1957 to 1959 of a major shift.

The Beta coefficients for Ghana move closely together in Figure 5. But is the Pareto distribution a good fit? Figure 6 shows the M curves for odd numbered years (minimum of 75 observations). The curves are definitely not horizontal over the range shown. They decline more sharply than those in the Gambia. At the same time, they level off, and for the last 0.25 per cent they are close to horizontal. In 1957, a regression of the $M$ values on (1-F) over the range from 0 to 0.25 per cent yields an insignificant coefficient of 9.9 with a standard error of 28.6. The Pareto distribution may for this range be a reasonable approximation, although there are signs of an upturn at the end (within the top 0.05 per cent).

The Beta coefficients for Sierra Leone over the period from 1945 to 1960 evaluated using different proportions of the population are shown in Figure 7. In the top 0.1 per cent, the coefficients moved closely together. From 1945 there was a fall in concentration for ten years, which levelled off for the 
second half of the 1950s. In the year before independence (1960), the coefficient was around 1.4, which was similar to that in Gambia and below that in Ghana at the same time. It was comfortably below that in the UK, as it had been in almost all cases since 1946.

The Beta coefficient obtained with the share of the top 0.1 per cent in the top 0.25 per cent in Sierra Leone lies above the others in Figure 7, and this suggests that the $M$ curves slope down, as is shown for even numbered years in Figure 8 (minimum of 50 observations). There is a distinct downward slope in all years and there is no convergence to a Pareto distribution in the top 0.25 per cent. If anything there is an upturn at the end.

The Beta coefficients for Nigeria over the period from 1952 to 1959 evaluated using different proportions of the population are shown in Figure 9. The estimates cover a smaller fraction of the population. Even though taxpayers made up some 1 per cent of the total population, the great majority were included in the lowest open range (below £300 per annum) in the statistical tables. There are therefore no estimates for the top 0.25 per cent, and the more limited range should be borne in mind when comparing across countries. This is significant, since it may be seen that the Beta coefficient from the share of the top 0.05 per cent in the top 0.1 per cent is distinctly higher than for the coefficients from higher up the distribution, a point to which we return. The other two coefficients move closely together and indicate a decline from around 1.8 in 1952 to around 1.45 in 1959, just before independence. In the first of these years, the coefficient was close to that in the UK; by the end of the 1950s, Nigeria was less concentrated than the UK.

Figure 10 shows the $M$ curves for Nigeria. It may be seen that the curves become steep once we move down below the 0.05 percentile; it is for this reason that the Beta coefficient from the share of the top 0.05 per cent in the top 0.1 per cent is distinctly higher in Figure 9. For the range as a whole, the Pareto distribution clearly does not apply. The clustering around 1.5 suggests that the Pareto may apply to the top 0.05 per cent, but there are signs of an upturn. A regression for 1952, for example, shows

$$
\begin{array}{ccc}
M= & 1.83+4.26(1-F)-0.0019(1-F)^{2} & R^{2}=0.916 \\
(0.56) & (0.0005) &
\end{array}
$$

\section{Conclusions}

The principal findings regarding the shape of the upper tail are summarised below: 


\begin{tabular}{|l|l|l|l|}
\hline & Colonial period & At independence & Pareto? \\
\hline Gambia & $\begin{array}{l}\text { Large fall in concentration } \\
\text { (B) from around 2 to less } \\
\text { than 1.5. }\end{array}$ & $\begin{array}{l}\text { Concentration } \\
\text { below 1.5. }\end{array}$ & $\begin{array}{l}\text { Not Pareto. Strong fall of } \mathrm{M} \\
\text { with F. }\end{array}$ \\
\hline Ghana & $\begin{array}{l}\text { Slight fall in concentration in } \\
\text { the 1950s before } \\
\text { independence. }\end{array}$ & $\begin{array}{l}\text { Concentration } \\
\text { around 1.7. }\end{array}$ & $\begin{array}{l}\text { Fall in M, converging to } \\
\text { Pareto for top 0.25 per } \\
\text { cent, although signs of } \\
\text { upturn at end. }\end{array}$ \\
\hline Nigeria & $\begin{array}{l}\text { Fall in concentration from } \\
1.8 \text { to 1.45 in 1950s. }\end{array}$ & $\begin{array}{l}\text { Concentration } \\
\text { around 1.45. }\end{array}$ & $\begin{array}{l}\text { Not Pareto. Strong fall with } \\
\text { F, but sign of up-turn at } \\
\text { end. }\end{array}$ \\
\hline Sierra Leone & $\begin{array}{l}\text { Large fall in concentration } \\
\text { from above 2 in 1945 to } \\
\text { around 1.45 in 1955, then } \\
\text { stable. }\end{array}$ & $\begin{array}{l}\text { Concentration } \\
\text { around 1.4. }\end{array}$ & $\begin{array}{l}\text { Not Pareto. Strong fall with } \\
\text { F, but sign of up-turn at } \\
\text { end. }\end{array}$ \\
\hline
\end{tabular}

Ghana appears to stand out from the other three countries in that there was a less marked fall in concentration during the colonial period before independence, and it entered independence with a higher level of concentration. This does not support the belief that Ghana was a relatively egalitarian country - at least at the top. The top of the distribution in Ghana approached more closely to the Pareto form than in the other countries, where the Pareto appeared an unsatisfactory assumption, missing important features of the form of the upper tail.

\section{Control totals for income}

The starting point for the control total for total household income is national income. The difficulties in calculating national income in Africa are widely recognized, and there is much criticism of contemporary macroeconomic statistics. Nonetheless, there is a long history of research on national accounts in Africa. Indeed, work on national accounts in a number of African colonies developed at much the same time as official national accounts were coming into use in OECD countries. The Second Conference of Colonial Government Statisticians in 1953, for example, could report (Colonial Office, 1954, page 41) estimates of national income for, among others, the Gold Coast and Nigeria.

\section{The Gambia}

In its An economic survey of the colonial territories, the Colonial Office stated that

"The data available for the calculation of the national income of the Gambia are inadequate for any correct assessment. Such information as exists, however, indicates that the national income of the territory in 
1948 might have been of the order of $£ 2 \frac{1}{2}$ to $€ 3$ million (of which at least half was derived from the groundnut trade)" (1951, page 9).

In the Colonial Digest of Statistics, November/December 1957, a tentative estimate of national income of the Gambia in 1956 was given as $\mathrm{f6}$ million. However, the first official series was not released until February 1981, considerably after the period considered here. As described by the Central Statistics Department in the 1980s,

"The history of preparation of national accounts in The Gambia is of very recent origin. The first series of gross domestic product for the country was prepared in late sixties by the staff members of World Bank who worked out GDP estimates for the years $1963 / 64$ to $1966 / 67$. [Later estimates were prepared in Gambia for $1967 / 68$ to 1970/71.] Comparable figures for the subsequent years were prepared annually by the Statistics Department. However, on account of the very scanty statistical information available at the time, these figures continued to be extremely weak. These figures were regarded to have limited utility and as such have not been published by the Statistics Department so far" (1985, para 1.4).

In view of these reservations about the earlier estimates, I have decided not to use income totals. The results for the Gambia are limited to those that require only population totals.

\section{Ghana}

Official estimates of national income in Ghana date from 1955. According to Birmingham, Neustadt and Omaboe, "national accounting in Ghana has traditionally been based on expenditure" (1966, page 39). As such, the national income figures for the period covered here are not easily related to the income side of the accounts. Moreover, the estimates of private consumption expenditure relied at that time on household surveys extrapolated using population figures. We have seen that there was probably substantial under-enumeration in the 1948 census, and the expenditure surveys have also been the subject of criticism (see Birmingham, Neustadt and Omaboe, 1966, page 40). As a result, the first official GNP estimates dating from 1955 were revised substantially (see Killick, 1978, page 85), and these revised GNP figures have been used here as the base series for the years 1955 to 1959 (from Birmingham, Neustadt and Omaboe, 1966, page 40).

In order to go back before 1955, I have linked to the GDP series published in Mitchell (1982, page 720). The series are linked at 1955: i.e. the 1954 figure is equal to Mitchell 1954/Mitchell 1955 times the 1955 base figure. For the fiscal years 1948-9, 1949-50 and 1950-51, I have linked at 1950 to the estimates of the Gross Territorial Product (GTP) made by Seers and Ross (1952, Tables I and II). This estimate does not include the value of subsistence agriculture, and it is not therefore surprising that their figure for 1950-51 at 
£152 million for GTP at market prices is below the figure for 1950 given by Mitchell, which is $\mathrm{E} 203$ million. Linking the two series at 1950 means that allowance is made for the value of subsistence output, on the assumption that the adjustment is proportionate. The two links (at 1955 and 1950) raise the figure for 1948-9 from $\mathrm{E} 98$ million to $\mathrm{E} 148$ million. This is a very substantial adjustment, and provides an indication of the possible margins of error in the estimate of national income. In the absence of earlier national accounts estimates, I have applied the money wage index given by Ewusi (1971, Table 9) (= 122 in 1943 and 183 in 1948) to take this figure back to $\mathrm{E} 99$ million in 1943, the first year in the income tax series.

Some check on the 1943 figure is provided by the report on the 1931 census, which contained "an estimate of the national income of the Gold Coast 1930-31 (Cardinall, 1932, page 120). It is noted that "hitherto no such valuation has ever been undertaken" and the estimate is "admittedly tentative". The author proceeds by attempting to calculate "the sum total of the joint incomes of all the inhabitants", and arrives at a total of $£ 58.8$ million, including noncash production. The estimate cannot however be said to be constructed according to modern national accounts principles, with apparent doublecounting. As such, it is more interesting as a contemporary judgment of the standard of living, and it should be noted that the author describes the resulting total as "an obvious under-estimate" (1932, page 122). The wage index would take the 1943 figure back to $\mathrm{E} 81$ million in 1939, which would not be inconsistent with this view of the 1931 estimate.

The final step is to move from national income to household income. The fact that the official national accounts were constructed on an expenditure basis means that it is not easy to make links to the factor incomes. The estimates of Seers and Ross, however, did contain both expenditure and revenue accounts. For 1949-50, household income was $£ 82.9$ million (1952, page 18 of appendix), when income at factor cost was $£ 112$ million, giving a proportion of 74 per cent, which has to be increased to allow for subsistence income. An alternative perspective is provided by the expenditure side of the national accounts (UN Yearbook of National Accounts Statistics 1966, pages 223-224). Over the period 1955 to 1959, total consumption expenditure of households and private non-profit institutions averaged 76 per cent of GNP at market prices. This falls short of total household income to the extent that there are positive savings and exceeds it to the extent that non-household spending is included and that there are items, such as imputed rents, not included in the income definition. In the absence of any firmer evidence for the period, a proportion of 75 per cent is taken throughout.

The resulting household income totals for Ghana are given in Table A.2. It should be emphasised that the underlying national accounts figures are subject to considerable qualification. After reviewing the available sources, Ady concluded in the early 1960s that "given all these potential sources of 
error and of differences in usage, the interpretation of the resulting aggregates of national product is subject to serious limitations" (1963, page 55). As with the population total, however, the limited purpose for which the total is being employed is to provide a measure of scale and for this purpose the estimates in Table A.2 provide a reasonable starting point. At the same time, the possible margins of error are undoubtedly larger for income totals than for the population totals.

\section{Nigeria}

In 1950, Prest and Stewart were asked by the Colonial Office to make estimates of national income for Nigeria. Their work, and that of Okigbo (1962), was based on the output and expenditure tables, since income-based estimates were not easy to obtain. As Okigbo explains "under Nigerian conditions income estimates will for some time to come remain unobtainable" (1962, page 5). The main problem, he judged, lay with estimates of business income. In the case of extra-territorial companies, "it was not unusual for the Nigerian branch not to know the magnitude of the profit made in Nigeria" (1962, page 5). The income of unincorporated businesses could only be obtained as a residual, but this was the largest component of the income estimates. He concludes that "the income approach to national accounts in countries like Nigeria is of dubious value" (1962, page 5).

The figures used here are from the later official figures. The series used is for GDP at factor cost from the Annual Abstract of Statistics, 1966, page 155. The fact that there are no income side accounts means that there is little basis for estimating household income. In the absence of any firm evidence, a round proportion of 80 per cent has been applied, on the basis of the experience of Ghana (see above) and East Africa (Atkinson, 2013). The resulting series is given in Table $\mathrm{A} 2$.

\section{Sierra Leone}

In his Economic survey of Sierra Leone, Jack (1958, page 66) refers to the tentative estimates of national income in 1956 published in the Colonial Digest of Statistics, November/December 1957. These give a figure for Sierra Leone of $\mathrm{£} 31.5$ million, but this does not seem a sufficient basis. It was only some ten years later, in September 1966, that the Central Statistics Office in Freetown published the first detailed estimates of national income in Sierra Leone. In June 1967, a revised version was published with figures for the years 1963-64, 1964-65 and 1965-66 for GDP and GNP at market prices. This postdates the availability of income tax data. In the light of this, no income control totals are used here. The results for Sierra Leone, like those for the Gambia, are limited to those that require only population totals. 


\section{Conclusion}

The limited national accounts information means that there are income control totals for only two of the four countries: Ghana and Nigeria. For these two countries, the estimates are surrounded by considerable uncertainty. At the same time, they allow us to have a first look at top income shares in two important West African countries.

\section{Top income shares}

The limited national accounts data for the African colonies means that the most commonly cited top income figures - those for income shares - are only available for two of the colonies, Ghana and Nigeria. The estimated income shares for Ghana from 1943 to 1959 are shown in Figure 11, together with corresponding shares in the UK (shown by hollow symbols and dashed lines). Initially the top income shares were lower than in the UK. In 1951, the top 0.1 per cent received 2 per cent of total income. This was 20 times their proportionate share, but less than in the UK, where the corresponding figure was 32 times. The top 0.01 per cent received 54 times their share in Ghana, but 85 times in the UK in 1951. Such differences cannot be explained by errors in the control total, since eliminating the difference would require that the total for Ghana be nearly halved, which is not plausible.

The first part of the 1950s saw little change in the top shares in Ghana. Indeed, in the year before independence (1956) the shares were higher than in 1951. The share of the top 0.1 per cent was 2.5 per cent. Since the top shares were falling in the UK, there was little effective difference by 1957: the shares of the top groups were essentially identical in Ghana and the UK. After independence, however, the top shares fell, so that the top 0.1 per cent in 1959 received 1.7 per cent of total income, or 16 times their proportionate share.

In Nigeria, the top shares rose during the 1950s - see Figure 12 - to the extent that they rose above those in the UK by the year before independence (1959). In that year the share of the top 0.1 per cent was 3.3 per cent, compared with 2.3 per cent in the UK; they had 33 times their proportionate share, compared with 23 times in the UK. Since the ratio of the top share commencing at an income $y / \mu$ (where $\mu$ is the mean income) to their proportionate share may be seen as the product of $y / \mu$ and $M$, the ratio to $y$ of average income above $y$, we can decompose the change. In the previous section, we saw that $M$ had fallen over the 1950s in Nigeria, so that for the ratio to the proportionate share to have risen, the "entry level", $y / \mu$, must 
have increased. From Figure 13, it may be seen that this is indeed the case. The 0.1 percentile in Nigeria was 6.8 times the mean in 1954 but had risen to double (13.6) by 1959. The 0.01 percentile was 37 times the mean in 1954 but had risen to 50 times by 1959 . The top group was less concentrated ( $M$ was smaller) but it was harder to join the group.

The same decomposition helps understand the differences across countries. Figure 14 shows the top shares in Ghana (solid markers) and Nigeria (hollow markers). On the assumptions made, the estimated shares are close for much of the period. It is indeed striking that the shares in the mid-1950s should be so similar in countries that might well be expected to be quite different in their degree of inequality. The top shares do diverge at the end of the 1950s, a divergence that can be calculated, in the case of the share of the top 0.1 per cent, to be due in almost equal part to changes in the entry level, which fell in Ghana and rose in Nigeria, and to the rise in the $M$ ratio in Nigeria and the fall in Ghana.

In Figure 15 the top shares in Ghana and Nigeria are compared with those in Kenya (dashed lines), which are significantly higher. The share of the top 0.1 per cent in Kenya was some 6 per cent, compared with figures around 2 to 3 per cent in West Africa. The difference is attributable to the much higher entry level in the case of Kenya, since the degree of concentration is no higher or lower in Kenya. The 0.1 percentile in Kenya in this period was around 35, compared with values more like 10 to 15 in West Africa. The difference between West and East Africa is shown further in Table 1, which compares different countries in the year before independence in terms of concentration and top shares. There appears to be no systematic difference in the Beta coefficients. All except Ghana are below the UK figure in 1959. But the income shares are distinctly higher in East Africa, as shown for Kenya in Figure 15.

Finally, we should consider tax evasion/avoidance, which are likely to be major considerations. The impact on the findings described above depends on the context. To the extent that erosion affects all countries equally, then the comparative conclusions are unaffected. To the extent, as seems probable, that erosion is greater in the African colonies, the comparison with the UK is subject to qualification. It remains possible however that the impact is on the entry level rather than on shape of the distribution, which means that the income shares are, relatively, under-stated in the colonies but that the degree of concentration is unaffected. 
Table 1 Comparison of West and East Africa in year before independence

\begin{tabular}{|l|r|r|}
\hline & $\begin{array}{l}\text { Concentration (Beta } \\
\text { coefficient from share of } \\
\text { top 0.01 in top 0.1) }\end{array}$ & $\begin{array}{l}\text { Share of top 0.1 per cent } \\
\text { in total income }\end{array}$ \\
\hline Gambia 1964 & 1.30 & 2.45 \\
\hline Ghana 1956 & 1.72 & 3.27 \\
\hline Nigeria 1959 & 1.52 & 5.36 \\
\hline Sierra Leone 1960 & 1.37 & 6.54 \\
\hline Kenya 1962 & 1.42 & 4.68 \\
\hline Tanzania 1960 & 1.61 & 4.76 \\
\hline Uganda 1961 & 1.49 & 1.35 \\
\hline Zanzibar 1962 & &
\end{tabular}

\section{Conclusions}

The colonial income tax in West Africa was paid by a very small proportion of the population, predominantly but not exclusively non-African. The position of the colonial elites was known to be highly privileged, but the evidence from the income tax data allows us to say more.

In comparing their incomes with those in the UK, or other colonies, we need to distinguish between the concentration of incomes within the top and the share of total income accruing to the group as a whole. Concentration - in terms of the income gradient within the top group - was declining during the colonial period before independence. At independence, top incomes were less concentrated in the Gambia, Nigeria and Sierra Leone than in the UK at that time. Ghana differed in that there was a less marked fall in concentration during the colonial period before independence, and it entered independence with a higher level of concentration. This does not support the belief that Ghana was a relatively egalitarian country - at least at the top. Equally, the share of total income accruing to the top group was no lower than in the UK in the case of Ghana. It was higher in the case of Nigeria, and the colonial shares would be higher if, as seems likely to be the case, there was a greater extent of tax evasion and avoidance.

When focusing on the very top of the distribution, it has been customary to summarise the degree of concentration in terms of the Pareto coefficient, but the colonial evidence suggests that this is a poor description and one that misses important features. Only in the case of Ghana did the top tail converge to the Pareto form. In the other colonies, the income gradient in general became markedly less steep as the top was approached.

What happened after independence? In the case of the Gambia, there was a U-shaped curve: at the outset, the distribution was more concentrated 
than in the UK; by independence it was distinctly less concentrated; but by 1974 the degree of concentration had returned to its early 1950s level. On the other hand, the early years after independence in Ghana showed a fall in top income shares. It would be very interesting to know what happened next, here and in the other countries. 
Table A1 Income tax data for Ghana

\begin{tabular}{|c|c|c|}
\hline $\begin{array}{l}\text { Income } \\
\text { year }\end{array}$ & Source of data & Notes \\
\hline 1943 & $\begin{array}{l}\text { Report on the Income Tax Department for } \\
\text { the years } 1944-45 \text { and } 1945-46 \text {, Table IX }\end{array}$ & \\
\hline 1951 & $\begin{array}{l}\text { Report on the Income Tax Department for } \\
\text { the year 1953-54, Table XII }\end{array}$ & \\
\hline 1952 & $\begin{array}{l}\text { Report on the Income Tax Department for } \\
\text { the year 1954-55, Table XII(a) }\end{array}$ & \\
\hline 1953 & $\begin{array}{l}\text { Report on the Income Tax Department for } \\
\text { the year 1954-55, Table XII(b) }\end{array}$ & \\
\hline 1954 & $\begin{array}{l}\text { Report on the Income Tax Department for } \\
\text { the year 1955-56, Table XII }\end{array}$ & \\
\hline 1955 & $\begin{array}{l}\text { Report on the Income Tax Department for } \\
\text { the year 1956-57, Table XI }\end{array}$ & \\
\hline 1956 & $\begin{array}{l}\text { Report on the Income Tax Department for } \\
\text { the year 1957-58, Table XI }\end{array}$ & \\
\hline 1957 & $\begin{array}{l}\text { Report on the Income Tax Department for } \\
\text { the year } 1958-59, \text { Table XI }\end{array}$ & $\begin{array}{l}\text { Also in Statistical Yearbook 1961, } \\
\text { page } 139\end{array}$ \\
\hline 1958 & Statistical Yearbook 1962, page 157 & \\
\hline 1959 & Statistical Yearbook 1963, page 171 & \\
\hline
\end{tabular}

Table A1 continued Income tax data for Federal Nigeria

\begin{tabular}{|c|l|l|l|}
\hline Year & & $\begin{array}{l}\text { AR denotes Annual Report of the } \\
\text { Department of Inland Revenue }\end{array}$ & \\
\hline 1952 & $\begin{array}{l}\text { Year } \\
\text { starting 1 } \\
\text { April 1952 }\end{array}$ & $\begin{array}{l}\text { Digest of Statistics 1955, vol 4, no 1, } \\
\text { Table 11, numbers and total income }\end{array}$ & $\begin{array}{l}\text { Also (in less detail) in AR for } \\
\text { three years ended 31 } \\
\text { st March } \\
1953,1954 \text { and 1955, page 11 }\end{array}$ \\
\hline 1953 & $\begin{array}{l}\text { Year } \\
\text { starting 1 } \\
\text { April 1953 }\end{array}$ & $\begin{array}{l}\text { Digest of Statistics 1956, vol 5, Table 9, } \\
\text { numbers and total income }\end{array}$ & $\begin{array}{l}\text { Also (in less detail) in AR for } \\
\text { three years ended 31 } \\
\text { st March } \\
1953,1954 \text { and 1955, page 17 }\end{array}$ \\
\hline 1954 & $\begin{array}{l}\text { Year } \\
\text { starting 1 } \\
\text { April 1954 }\end{array}$ & $\begin{array}{l}\text { Digest of Statistics 1957, vol 6, no 1, } \\
\text { Table 9, numbers and total income }\end{array}$ & $\begin{array}{l}\text { Also (in less detail) in AR for } \\
\text { three years ended 31 } \\
\text { st March }\end{array}$ \\
\hline 1955 & $\begin{array}{l}\text { Year } \\
\text { starting 1 } \\
\text { April 1955 }\end{array}$ & $\begin{array}{l}\text { Digest of Statistics 1958, vol 7, no 4, } \\
\text { Table 9, numbers and total income }\end{array}$ & \\
\hline 1956 & $\begin{array}{l}\text { Year } \\
\text { starting 1 } \\
\text { April 1956 }\end{array}$ & $\begin{array}{l}\text { Digest of Statistics 1959, vol 8, no 4, } \\
\text { Table 9, numbers and total income } 23\end{array}$ \\
& $\begin{array}{l}\text { AR for the Year 1956/57, Table } \\
\text { 7, contains numbers by ranges } \\
\text { by nationality (African, } \\
\text { European, Levantine and } \\
\text { Asiatic) and same distributional } \\
\text { information as Digest of } \\
\text { Statistics }\end{array}$ \\
\hline 1957 & $\begin{array}{l}\text { Year } \\
\text { starting 1 } \\
\text { April 1957 }\end{array}$ & $\begin{array}{l}\text { Digest of Statistics 1959, vol 8, no 4, } \\
\text { Table 9, numbers and total income }\end{array}$ & $\begin{array}{l}\text { AR for the Year 1956/57, Table } \\
\text { 7, contains numbers by ranges } \\
\text { by nationality and same } \\
\text { distributional information as }\end{array}$ \\
\hline
\end{tabular}




\begin{tabular}{|l|l|l|l|}
\hline & & & Digest of Statistics \\
\hline 1958 & $\begin{array}{l}\text { Year } \\
\text { starting 1 } \\
\text { April 1958 }\end{array}$ & $\begin{array}{l}\text { Annual Abstract of Statistics 1961, } \\
\text { Table 33, numbers and total income }\end{array}$ & \\
\hline 1959 & $\begin{array}{l}\text { Year } \\
\text { starting 1 } \\
\text { April 1959 }\end{array}$ & $\begin{array}{l}\text { Annual Abstract of Statistics 1961, } \\
\text { Table 33, numbers and total income }\end{array}$ & \\
\hline
\end{tabular}

Table A1 continued Income tax data for Sierra Leone

\begin{tabular}{|c|l|}
\hline Year & $\begin{array}{l}\text { AR }=\text { Annual Report of the Income Tax } \\
\text { Department }\end{array}$ \\
\hline 1945 & AR 1946-1947, Table V \\
\hline 1946 & AR 1947-48, page 6 (amounts only) \\
\hline 1947 & \\
& AR 1948-49, page 5 (amounts only) \\
\hline 1948 & \\
\hline 1949 & AR year ended 31 Mar 1951, page 12 \\
\hline 1950 & AR year ended 31 Mar 1952, page 11 \\
\hline 1951 & AR year ended 31 Mar 1953, page 9 \\
\hline 1952 & AR year ended 31 Mar 1954, page 8 \\
\hline 1953 & AR year ended 31 Mar 1955, page 7 \\
\hline 1954 & AR 1956, page 9 \\
\hline 1955 & AR 1957, page 6 \\
\hline 1956 & AR 1958, page 6 \\
\hline 1957 & AR 1959, page 6 \\
\hline 1958 & AR 1960, page 8 \\
\hline 1959 & AR year ended 31 Mar 1961, pages 7 and 8 \\
\hline 1960 & AR 1961/62, pages 6 and 7 \\
\hline
\end{tabular}

Table A1 continued Income tax data for the Gambia

\begin{tabular}{|l|l|l|}
\hline $\begin{array}{l}\text { Income } \\
\text { year }\end{array}$ & Source of data & Notes \\
\hline & FR = Financial Report for the year & \\
\hline 1944 & FR 1945, Appendix 9 & \\
\hline 1945 & FR 1946, Appendix 9 & \\
\hline 1946 & FR 1947, Appendix 9 & \\
\hline 1947 & FR 1948, Appendix 9 & \\
\hline 1948 & FR 1949, Appendix 9 & \\
\hline 1949 & FR 1950, Appendix 9 & \\
\hline 1950 & FR 1951, Appendix 9 & \\
\hline 1951 & FR 1952, Appendix 9 & \\
\hline 1952 & FR 1953, Appendix 9 & \\
\hline 1953 & FR 1954, Appendix 9 & \\
\hline 1954 & FR 1955, Appendix 9 & \\
\hline
\end{tabular}




\begin{tabular}{|c|c|c|}
\hline 1955 & FR 1956, Appendix 9 & \\
\hline 1956 & FR 1957, Appendix 13 & \\
\hline 1957 & FR 1958, Appendix 13 & \\
\hline 1958 & FR 1959, Appendix 14 & \\
\hline 1959 & FR 1960, Appendix 13 & \\
\hline \multicolumn{3}{|l|}{1960} \\
\hline \multicolumn{3}{|l|}{1961} \\
\hline \multicolumn{3}{|l|}{1962} \\
\hline 1963 & $\begin{array}{l}\text { AR = Annual Report of the Income } \\
\text { Tax Division of the Ministry of } \\
\text { Finance 1964, 1st and 5th schedules }\end{array}$ & First reference to schedules \\
\hline 1964 & AR $1965,1^{\text {st }}$ and 4 th schedules & \\
\hline 1965 & AR 1966, page 6 & \\
\hline 1966 & AR 1967, pages 5 and 6 & \\
\hline 1967 & AR 1968, pages 4 and 5 & \\
\hline 1968 & AR 1969, page 6 & \\
\hline 1969 & AR 1974, pages 10 and 15 & $\begin{array}{l}\text { Necessary to calculate number of cases } \\
\text { under } 4 \text { th schedule using the implied tax } \\
\text { rates by band (checked against 1968) }\end{array}$ \\
\hline 1970 & AR 1974, pages 10 and 15 & Ditto \\
\hline 1971 & AR 1974, pages 10 and 15 & Ditto \\
\hline 1972 & AR 1974, pages 10 and 15 & Ditto \\
\hline 1973 & AR 1974, pages 8 and 15 & \\
\hline 1974 & AR 1975, pages 6 and 10 & \\
\hline
\end{tabular}


Table A.2 Control totals

\begin{tabular}{|c|c|c|c|c|c|}
\hline Ghana & Ghana & Nigeria & Nigeria & Sierra Leone & The Gambia \\
\hline $\begin{array}{l}\text { Total tax } \\
\text { units } \\
\text { (thousands) }\end{array}$ & $\begin{array}{l}\text { Total } \\
\text { household } \\
\text { income } £ \\
\text { million }\end{array}$ & $\begin{array}{l}\text { Total tax } \\
\text { units } \\
\text { (thousands) }\end{array}$ & $\begin{array}{l}\text { Total } \\
\text { household } \\
\text { income £ } \\
\text { million }\end{array}$ & $\begin{array}{l}\text { Total tax } \\
\text { units } \\
\text { (thousands) }\end{array}$ & $\begin{array}{l}\text { Total tax } \\
\text { units } \\
\text { (thousands) }\end{array}$ \\
\hline
\end{tabular}

\begin{tabular}{|c|c|c|c|c|c|c|}
\hline 1943 & 1,556 & 74 & & & & \\
\hline 1944 & 1,595 & & & & & 101 \\
\hline 1945 & 1,634 & & & & 790 & 102 \\
\hline 1946 & 1,675 & & & & 793 & 104 \\
\hline 1947 & 1,717 & & & & 795 & 105 \\
\hline 1948 & 1,760 & 111 & & & 797 & 107 \\
\hline 1949 & 1,804 & 138 & & & 828 & 108 \\
\hline 1950 & 1,849 & 172 & & & 847 & 110 \\
\hline 1951 & 1,895 & 210 & & & 857 & 112 \\
\hline 1952 & 1,944 & 208 & 11,437 & 492 & 867 & 115 \\
\hline 1953 & 1,994 & 227 & 11,714 & 532 & 877 & 118 \\
\hline 1954 & 2,046 & 255 & 12,078 & 619 & 887 & 121 \\
\hline 1955 & 2,100 & 249 & 12,454 & 662 & 898 & 124 \\
\hline 1956 & 2,154 & 257 & 12,814 & 696 & 907 & 127 \\
\hline 1957 & 2,211 & 270 & 13,185 & 728 & 917 & 130 \\
\hline 1958 & 2,269 & 286 & 13,567 & 692 & 927 & 134 \\
\hline 1959 & 2,330 & 324 & 13,960 & 722 & 938 & 138 \\
\hline 1960 & 2,393 & 348 & & & 948 & 142 \\
\hline 1961 & & & & & & 145 \\
\hline 1962 & & & & & & 150 \\
\hline 1963 & & & & & & 154 \\
\hline 1964 & & & & & & 159 \\
\hline 1965 & & & & & & 163 \\
\hline 1966 & & & & & & 167 \\
\hline 1967 & & & & & & 172 \\
\hline 1968 & & & & & & 176 \\
\hline 1969 & & & & & & 181 \\
\hline 1970 & & & & & & 185 \\
\hline 1971 & & & & & & 191 \\
\hline 1972 & & & & & & 197 \\
\hline 1973 & & & & & & 203 \\
\hline 1974 & & & & & & 209 \\
\hline
\end{tabular}




\section{Bibliography}

Acemoglu, D and Robinson, J A, 2013, "Economics versus politics: Pitfalls of policy advice", Journal of Economic Perspectives, vol 27: 173-192.

Ady, P, 1963. "Uses of national accounts in Africa" in L H Samuels, editor. African studies in income and wealth, Bowes and Bowes, Cambridge.

Atkinson, A B, 2005, "Top incomes in the UK over the twentieth century", Journal of the Royal Statistical Society, vol 168: 325-343.

Atkinson, A B, 2013, "Top incomes in East Africa before and after independence”, unpublished.

Atkinson, A B, Piketty, T and Saez, E, 2011, "Top incomes in the long run of history", Journal of Economic Literature, vol 49: 3-71.

Birmingham, W, Neustadt, I and Omaboe, E N, editors, 1966 and 1967, A study of contemporary Ghana, volume One, 1966, and volume Two, 1967, Allen and Unwin, London.

Brewster, S P, 1954, Gold Coast income tax, Takoradi, Gold Coast.

Cardinall, A W, 1932, The Gold Coast, 1931, Government Printer, Accra.

Colonial Office, 1952-55, An economic survey of the colonial territories, three volumes, HMSO, London.

Colonial Office, 1954, Report of the second conference of Colonial Government Statisticians, 1953, Colonial No. 301, HMSO, London.

Cox-George, N A, 1973, Studies in finance and development: The Gold Coast (Ghana) experience 1914-1950, Dobson, London.

Ewusi, K, 1971, The distribution of monetary incomes in Ghana, Institute of Statistical, Social, and Economic Research, University of Ghana, Legon.

Frankema, E and Jerven, M, 2014, "Writing history backwards or sideways: towards a consensus on African population, 1850-2010", Economic History Review, vol 67: 907-931.

Gocking, R S, 2005, The history of Ghana, Greenwood Press, Westport.

Huq, M M, 1989, The economy of Ghana, Macmillan, London. 
Jack, D T, 1958, Economic survey of Sierra Leone, Government Printing Department, Freetown.

Kay, G B, editor, 1972, The political economy of colonialism in Ghana, Cambridge University Press, Cambridge.

Kennedy, T A, Ord, H W and Walker, D, 1963, "On the calculation and interpretation of national accounting material in East Africa" in L H Samuels, editor, African studies in income and wealth, Bowes and Bowes, London: 350432.

Killick, T, 1978, Development economics in action: A study of economic policies in Ghana, Heinemann, London.

Kuczynski, R R , 1948, Demographic survey of the British colonial empire, volume I, Cambridge University Press, London.

Lury, D A, 1963, "Review of Nigerian national accounts, 1950-57 by P N C Okigbo", Journal of Modern African Studies, vol 1: 411-413.

Maddison, A, 2003, The world economy: Historical statistics, OECD, Paris.

Mitchell, B R, 1982, International historical statistics: Africa and Asia, New York University Press, New York and London.

Myrdal, G, 1956, An international economy, problems and prospects, Harper Brothers.

Nkrumah, K, 1964, Consciencism, Heinemann, London.

Okigbo, P N C, 1962, Nigerian national accounts, 1950-57, Government Printer, Enugu.

Orewa, G 0, 1962, Taxation in Western Nigeria, Oxford University Press, Oxford.

Phillips, A 0, 1975, "Review of income distribution data: Ghana, Kenya, Tanzania and Nigeria", Research Program in Economic Development, Woodrow Wilson School, Princeton University, Discussion Paper 58.

Piketty, T, 2001, Les hauts revenus en France au $20^{\text {ème }}$ siècle, Grasset, Paris

Prest, A R and Stewart. I G, 1953, The national income of Nigeria, 1950-51, HMSO, London. 
Seers, D and Ross, C R, 1952, Report on financial and physical problems of development in the Gold Coast, Office of the Government Statistician, Accra. 
Figure 1 Taxpayers as per cent of total tax units

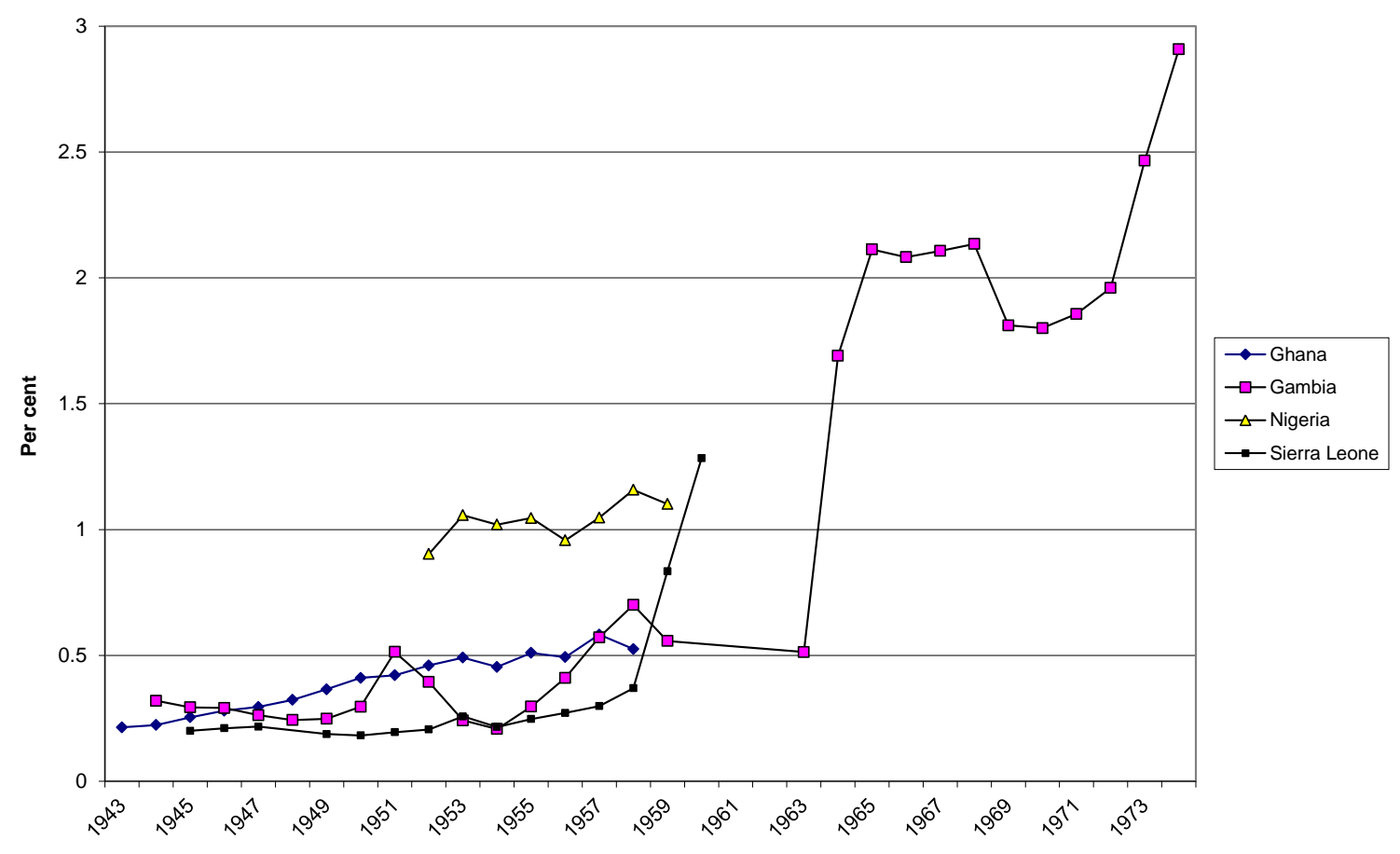

Figure 2 Beta coefficients Gambia 1944 to 1974

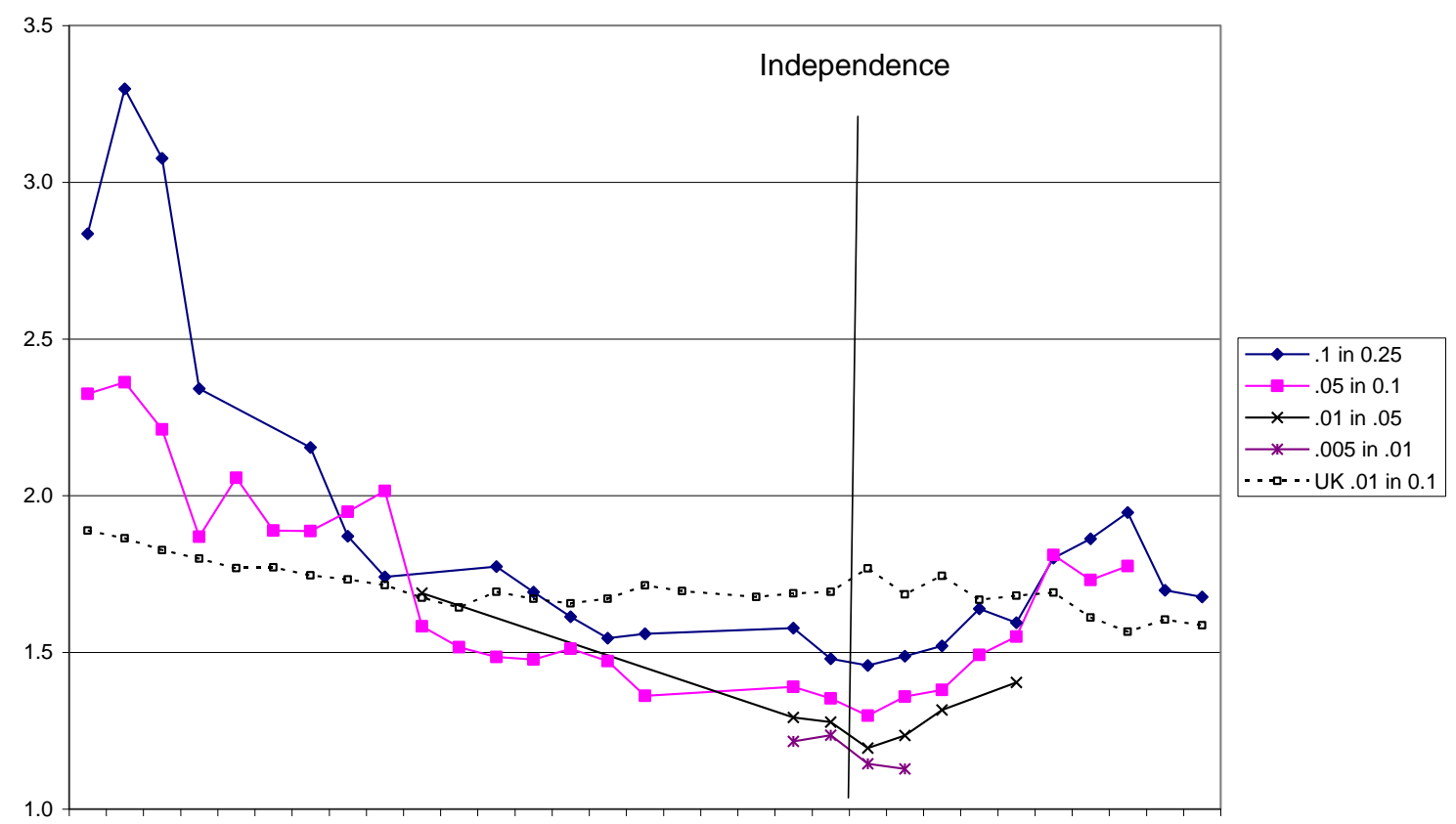

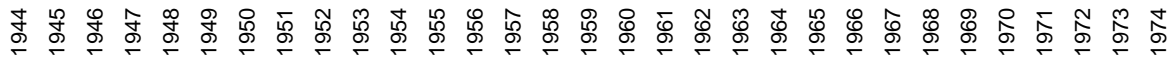


Figure $3 \mathrm{M}$ curves Gambia before independence (even years)

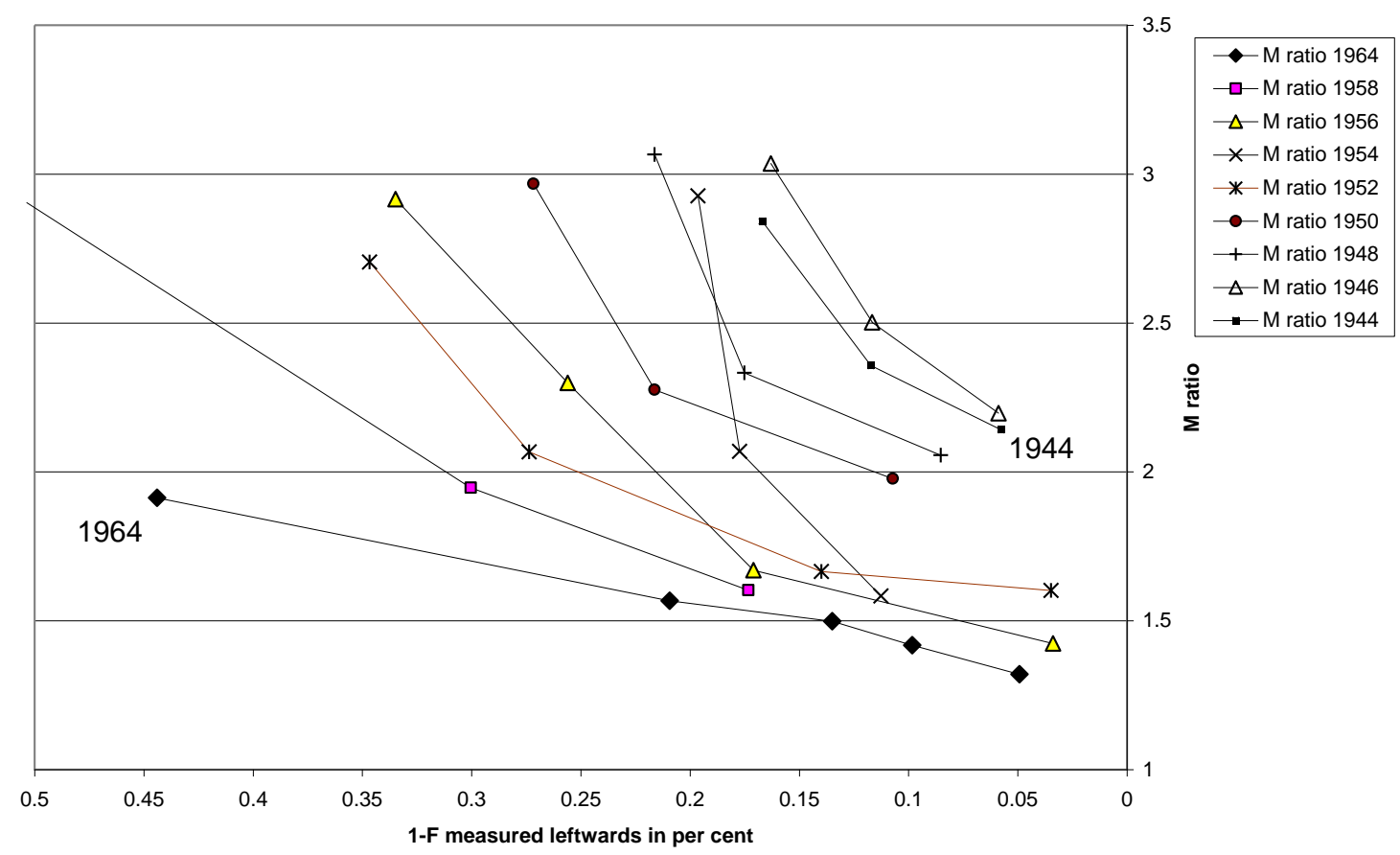

Figure $4 \mathbf{M}$ curves Gambia from independence (even years)

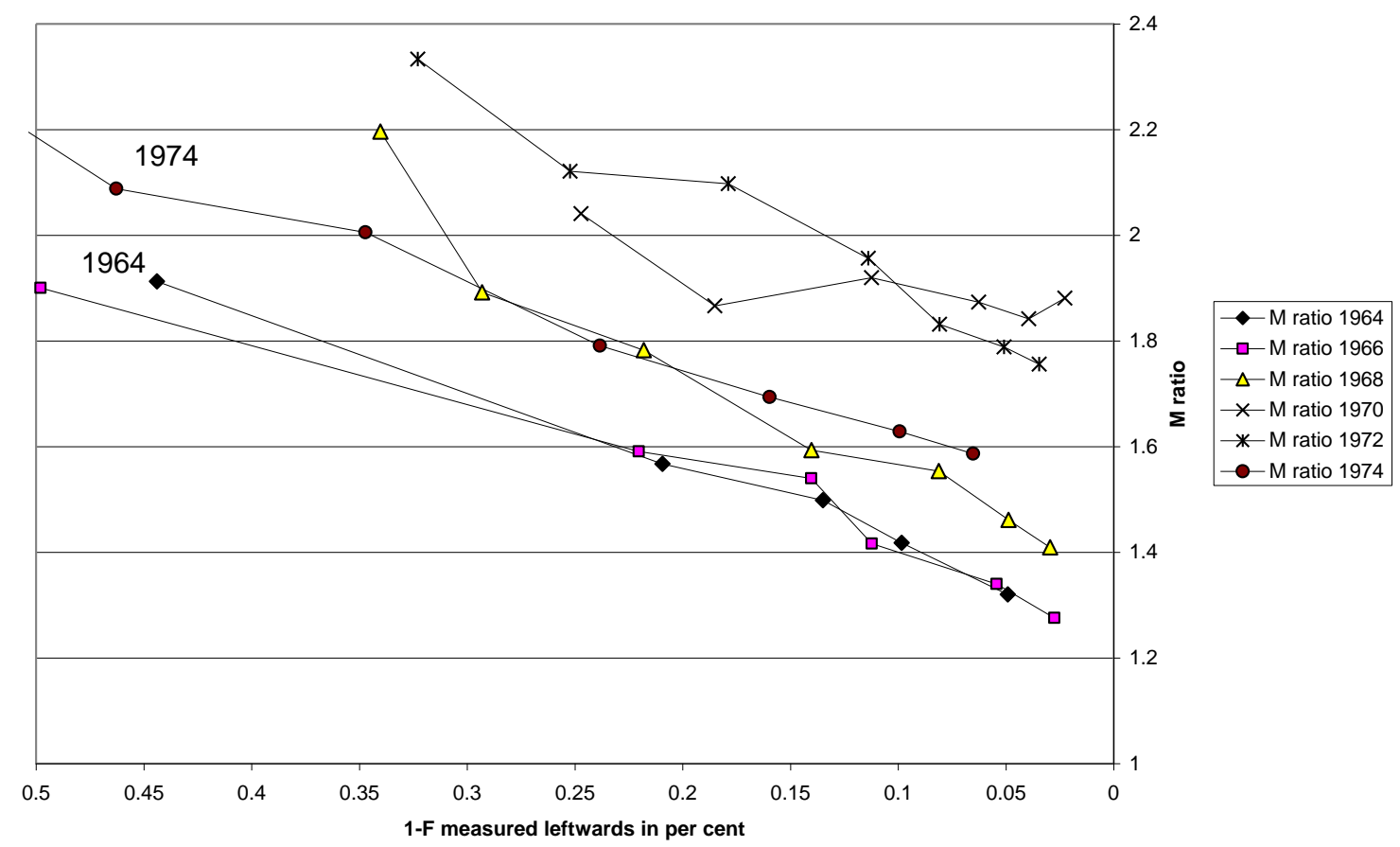


Figure 5 Beta coefficients in Ghana

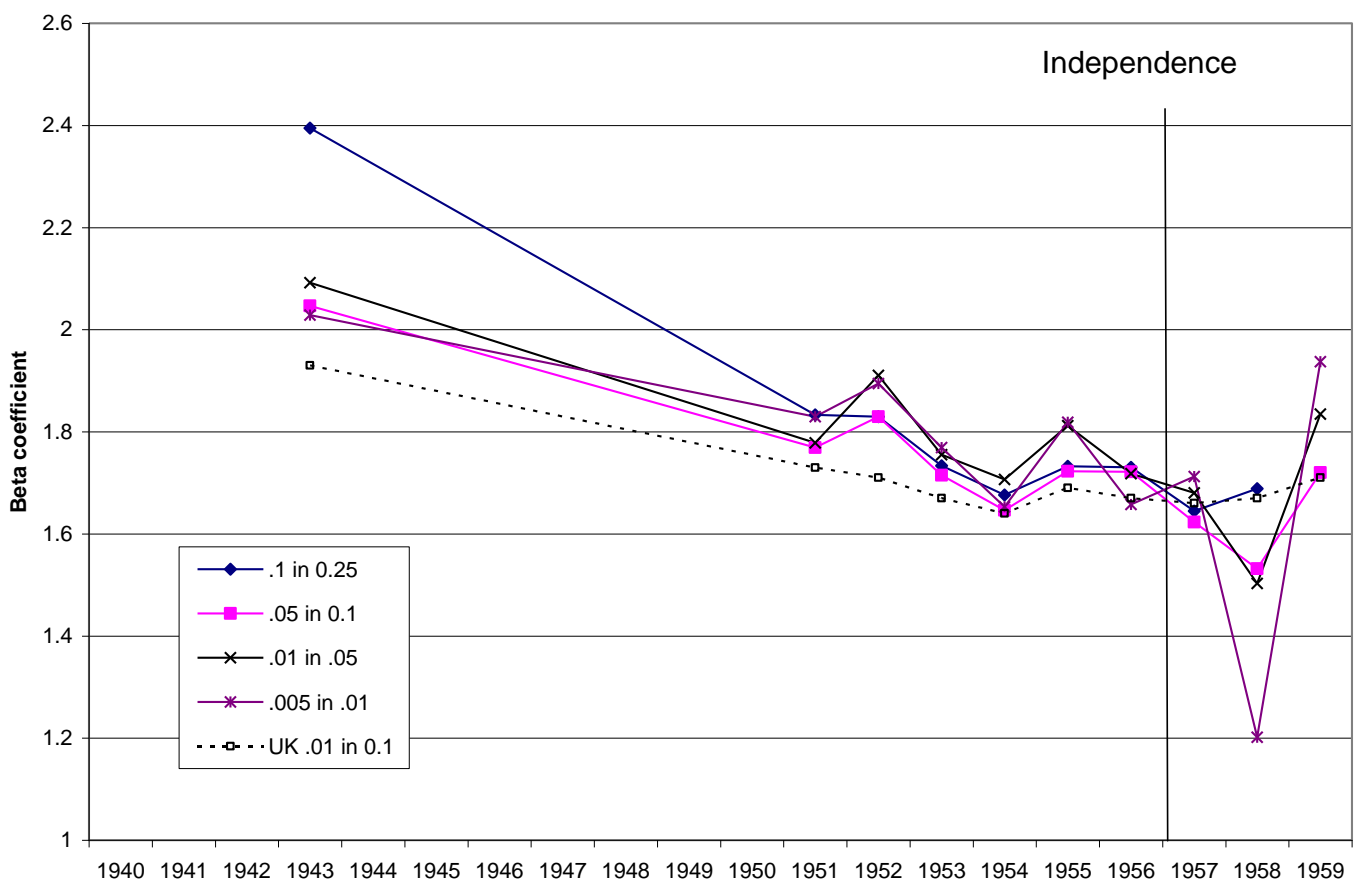

Figure $6 M$ curves Ghana (odd numbered years)

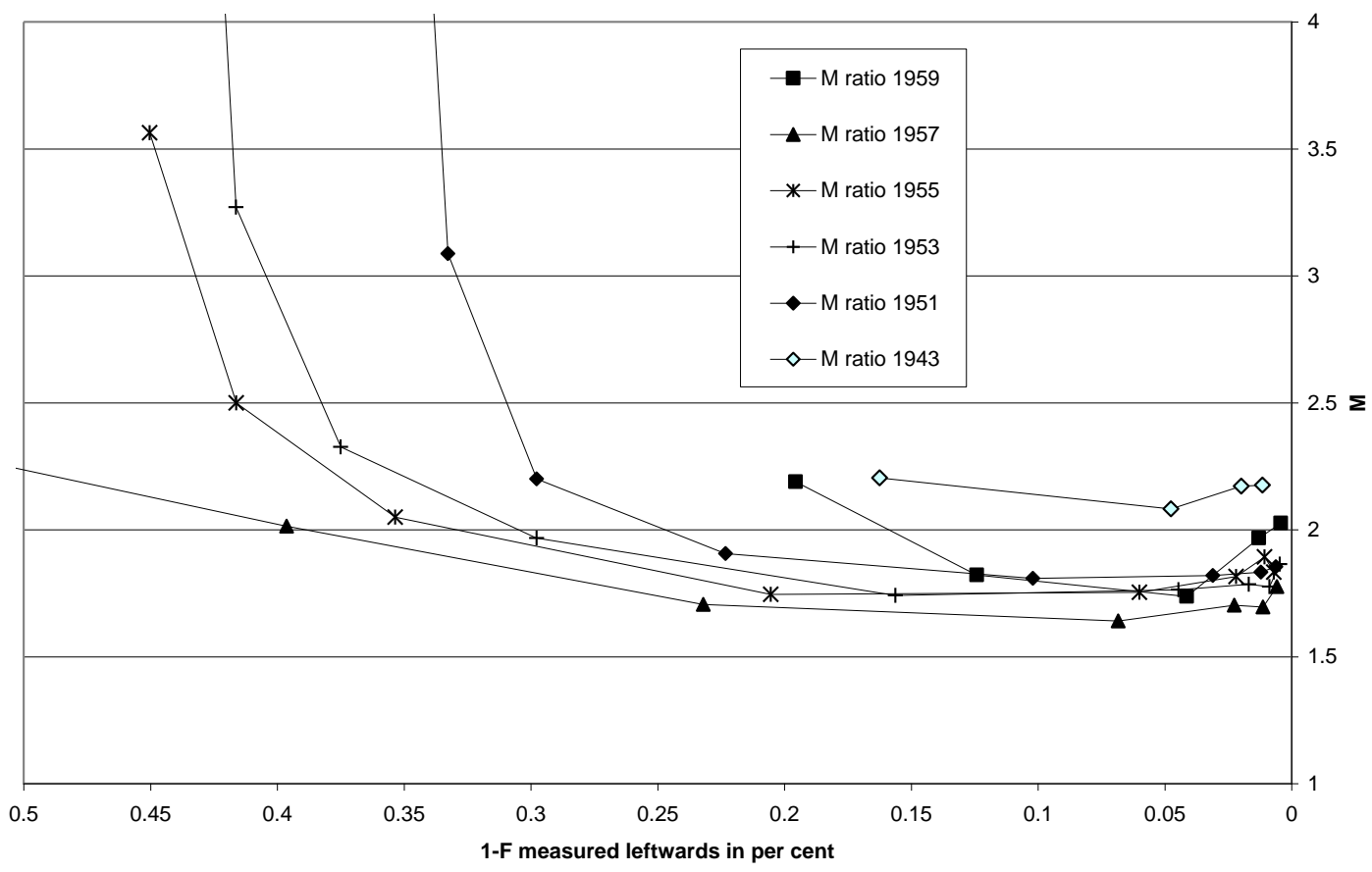


Figure 7 Beta coefficients Sierra Leone

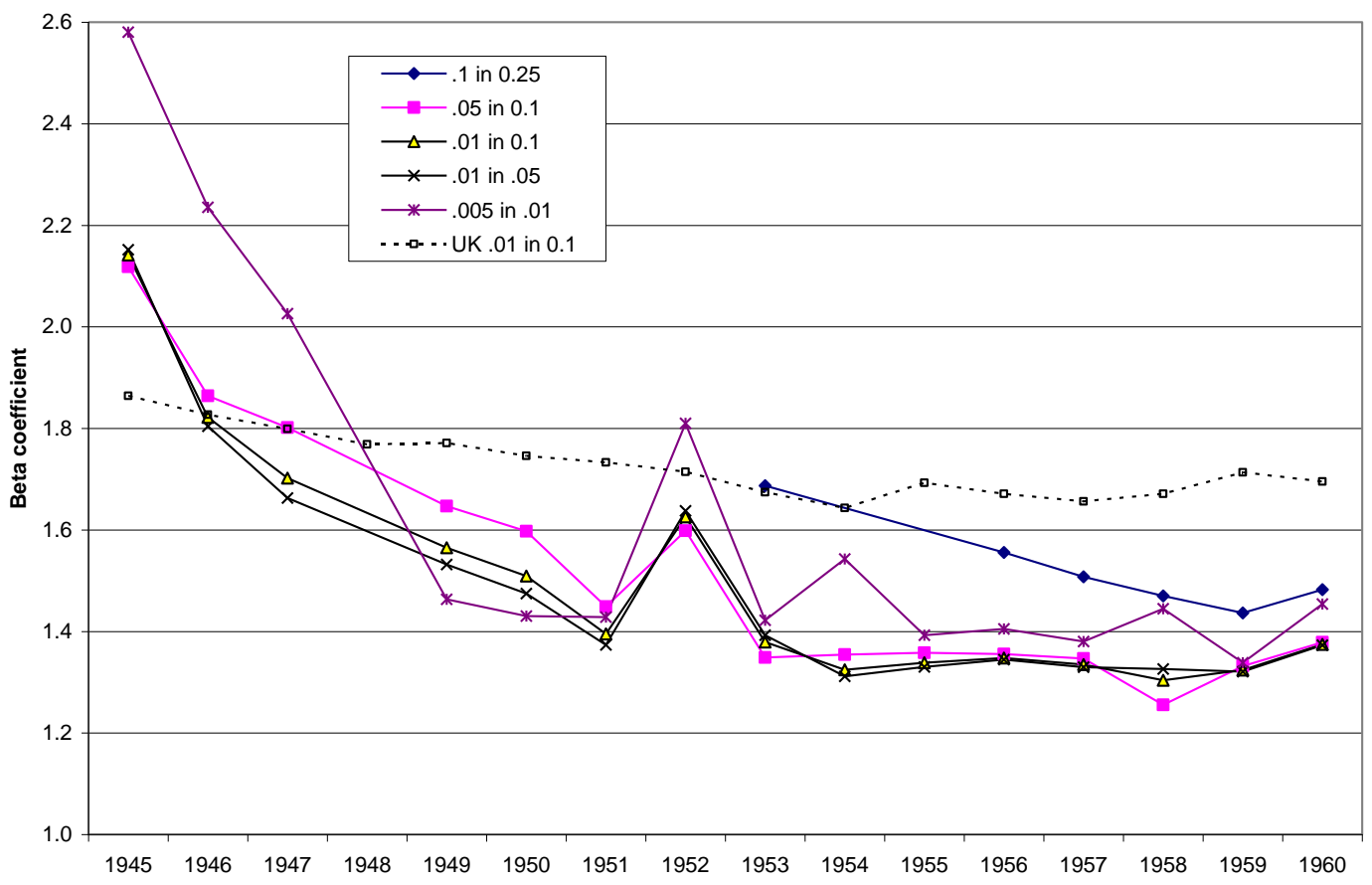

Figure $8 \mathrm{M}$ curves Sierra Leone (even numbered years)

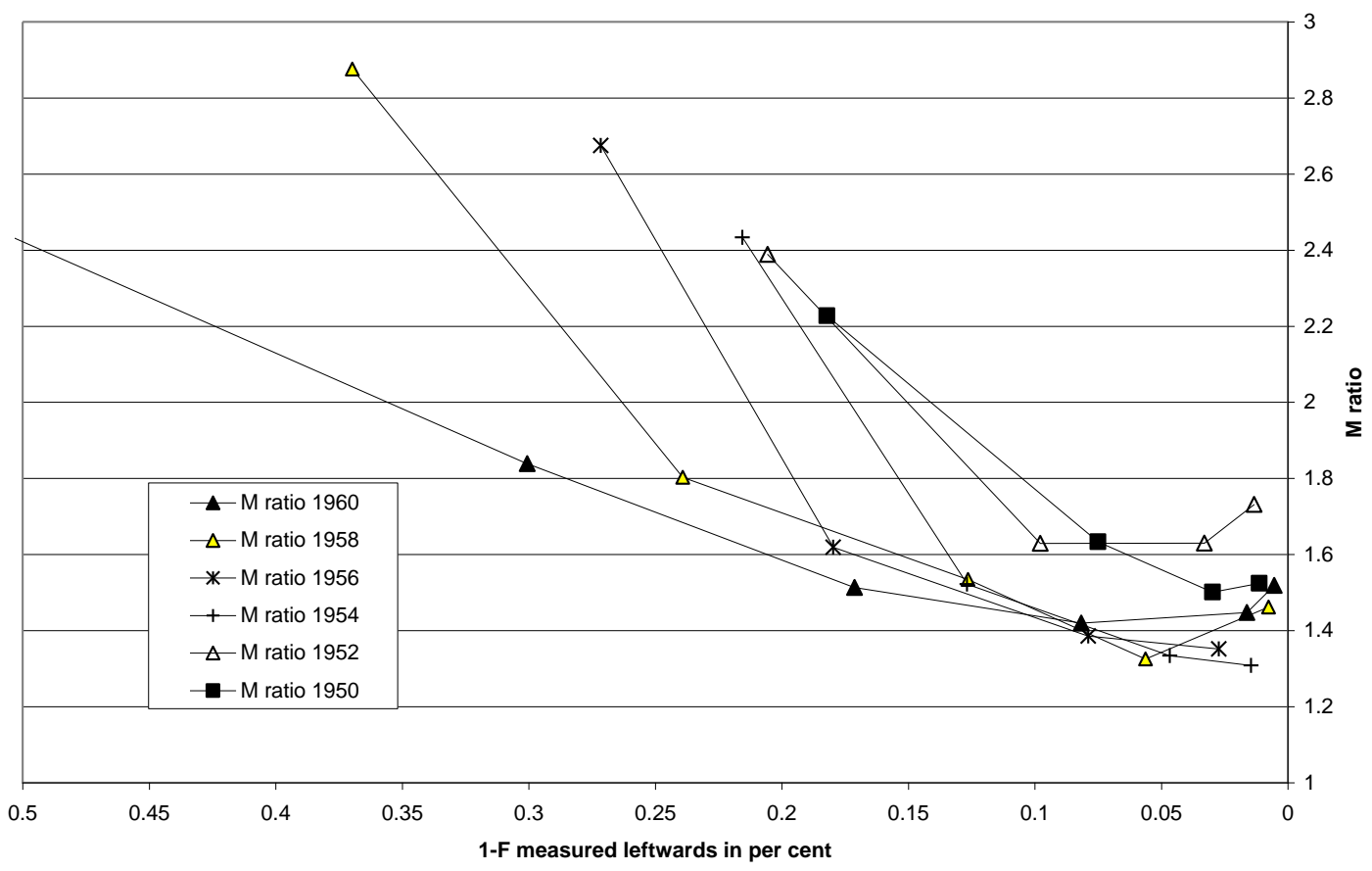


Figure 9 Beta coefficients Nigeria

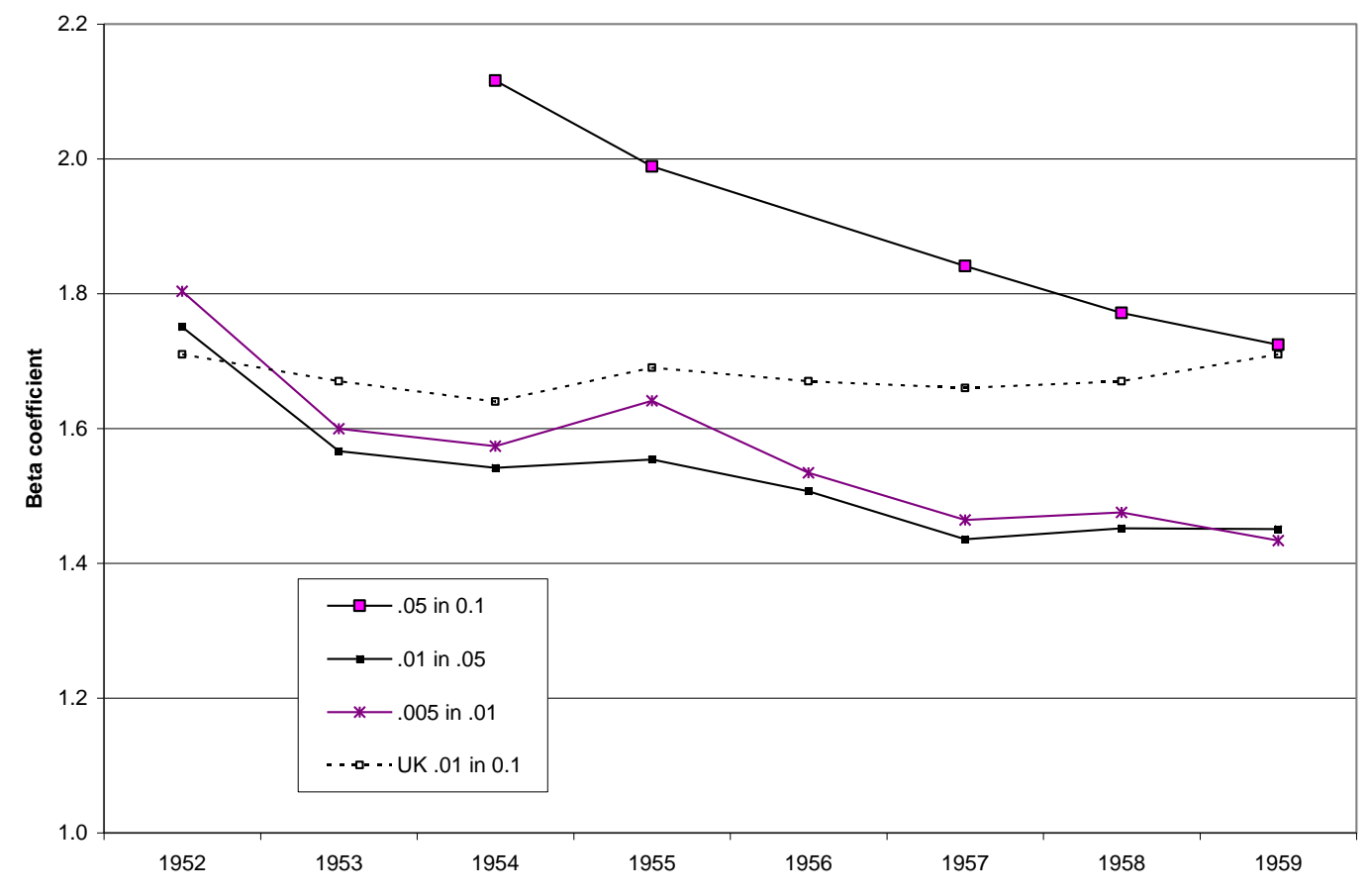

Figure $10 \mathrm{M}$ curves Nigeria

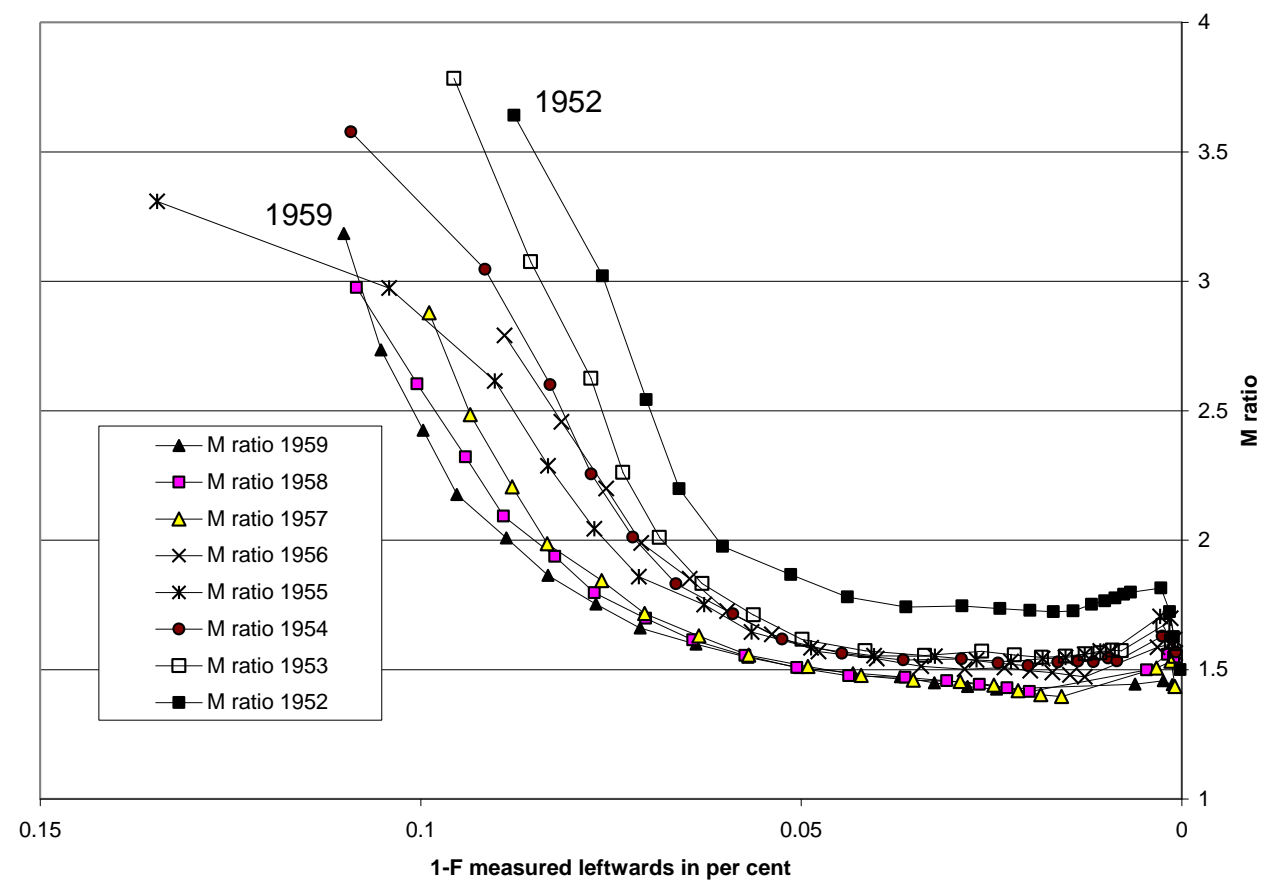


Figure 11 Income shares in Ghana

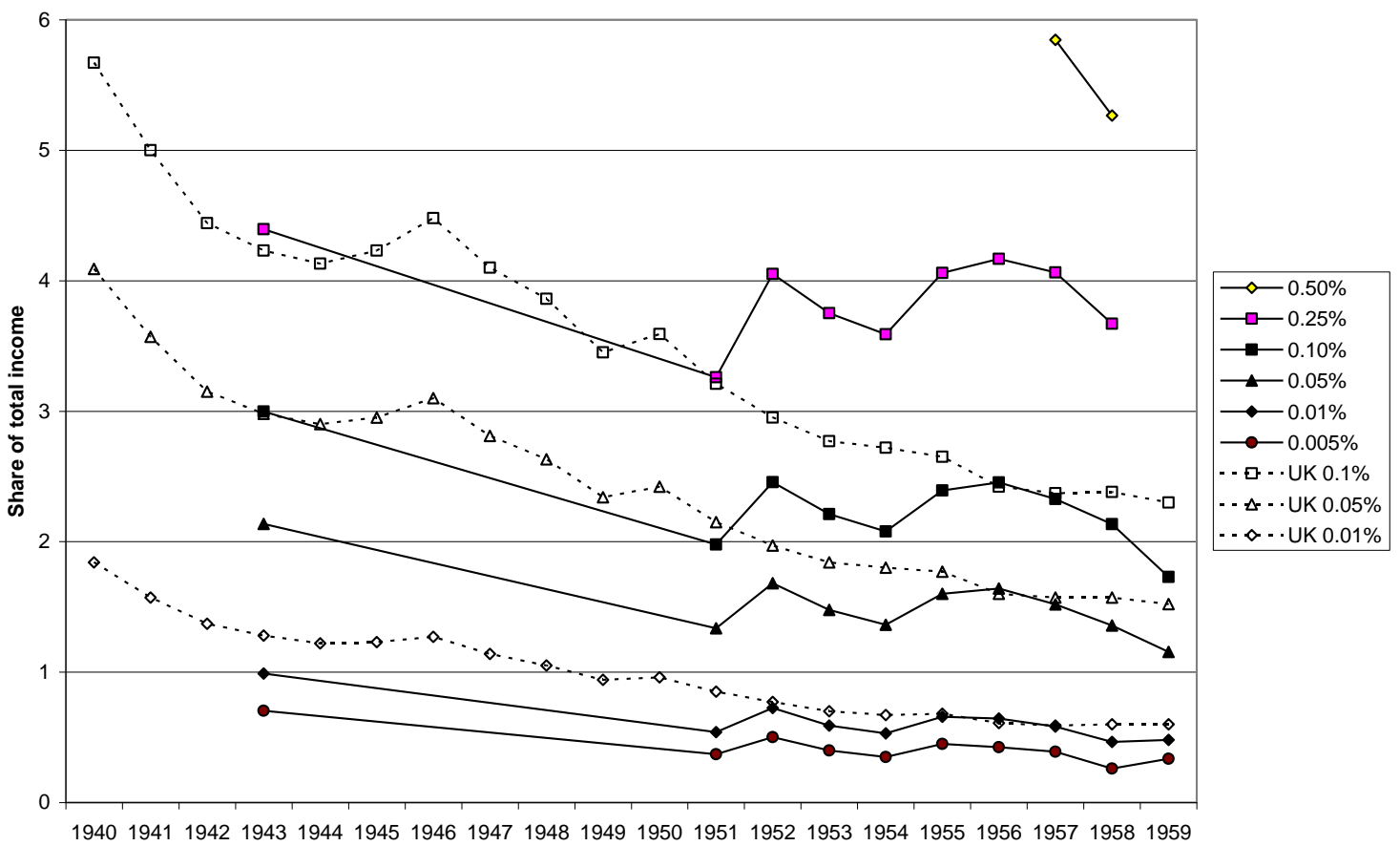

Figure 12 Income shares Nigeria

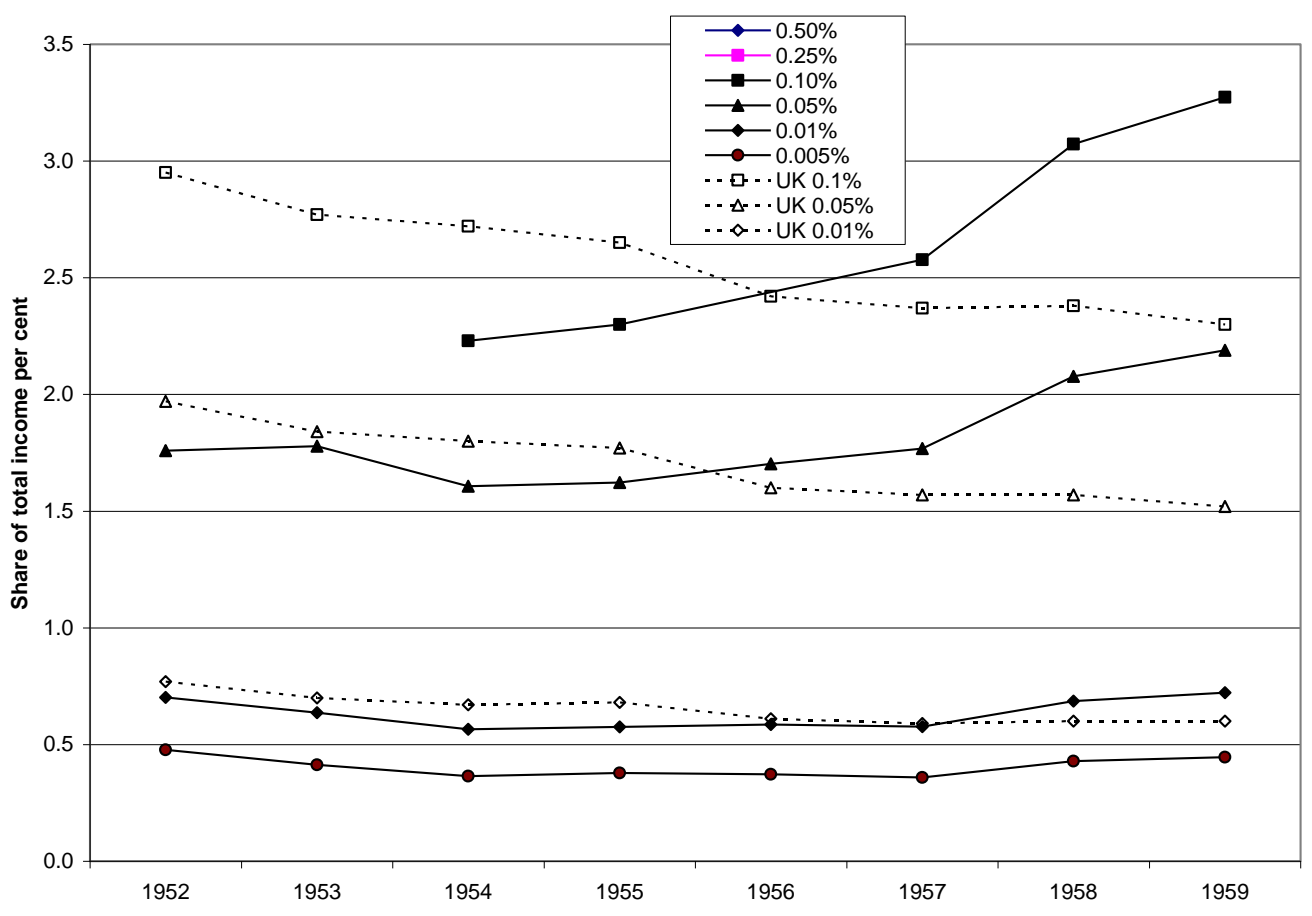


Figure 13 Percentiles as ratio to mean Nigeria

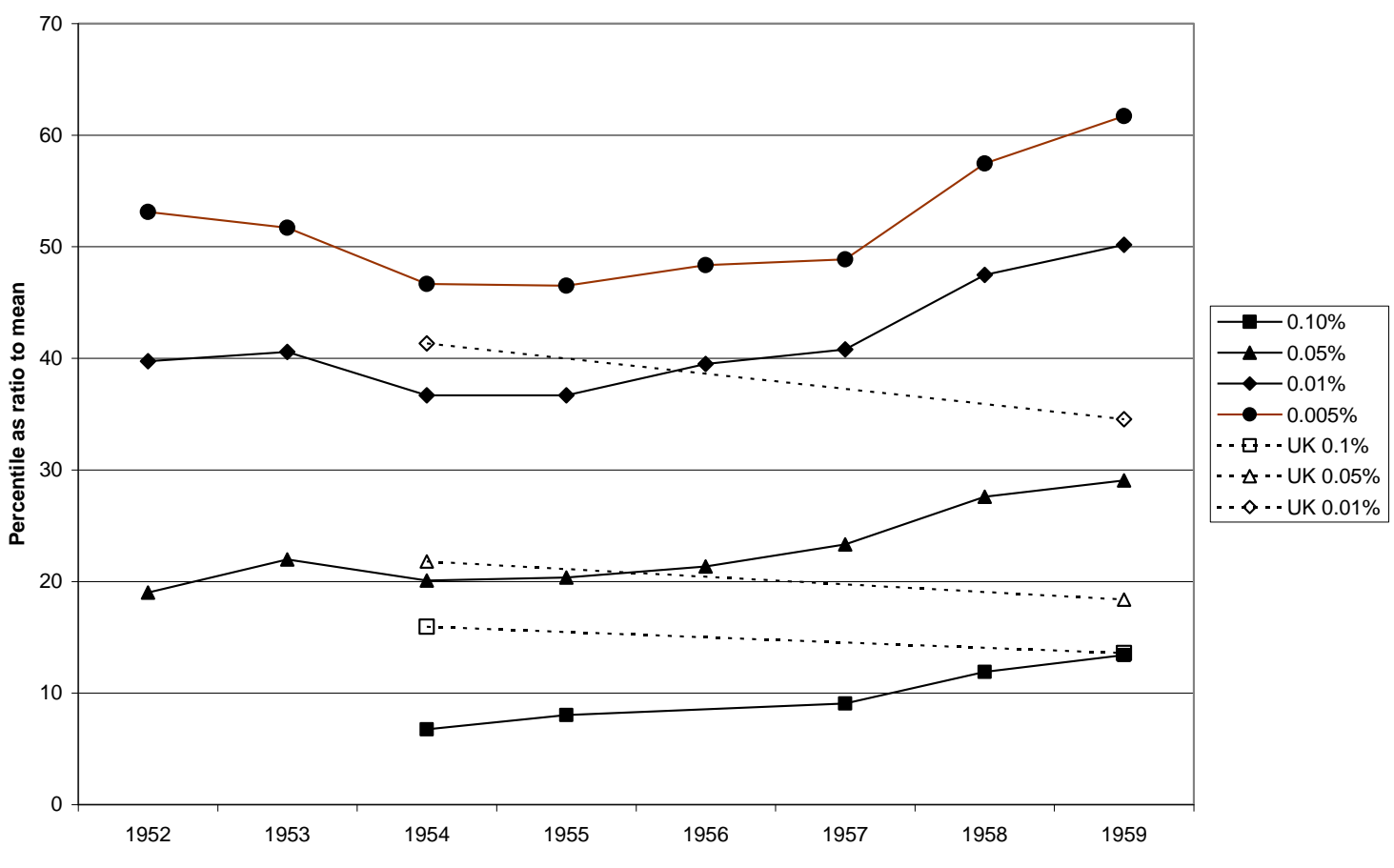

Figure 14 Top shares of Ghana and Nigeria compared

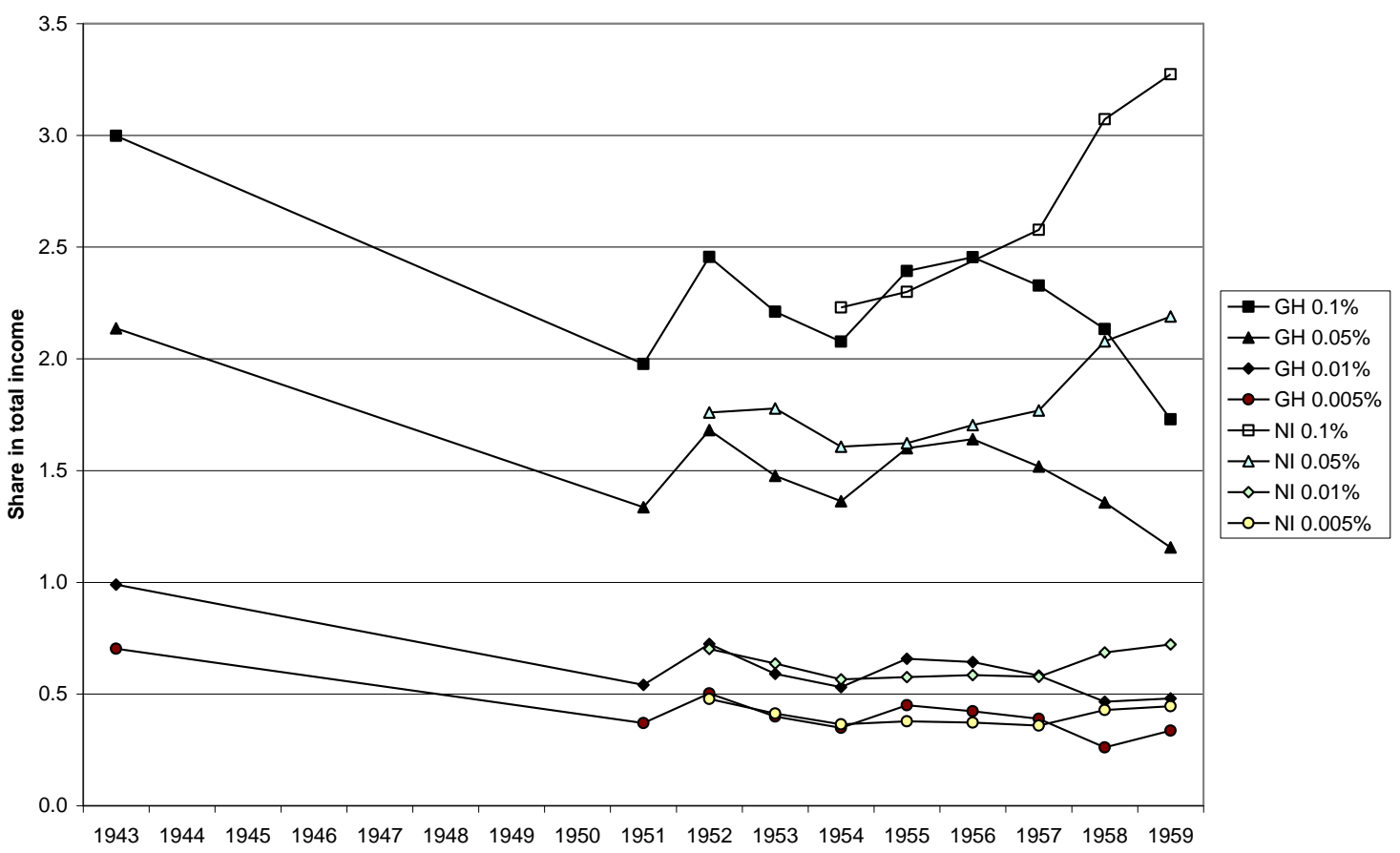


Figure 15 Top shares compared with Kenya

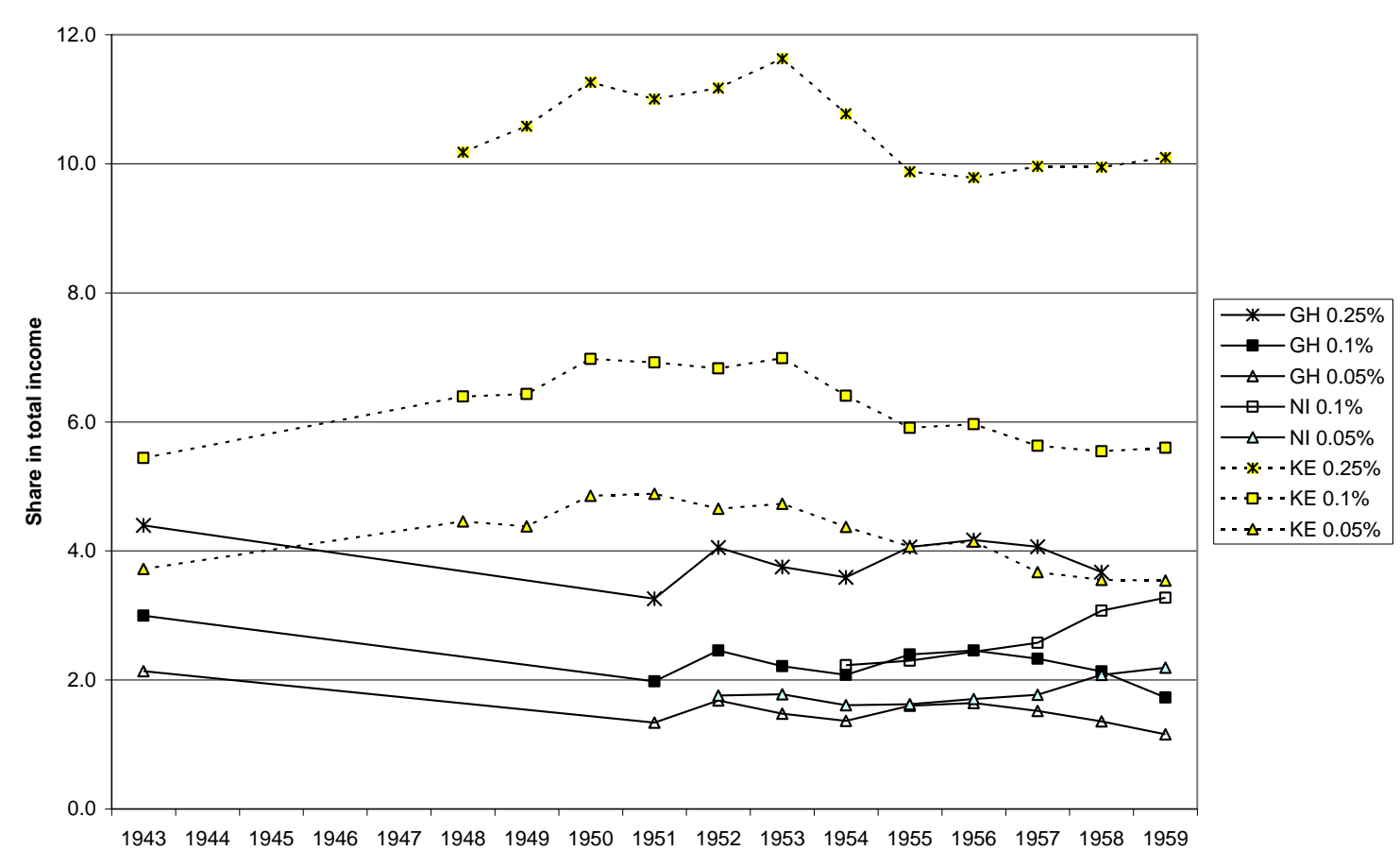

